UNITED STATES DEPARTMENT OF INTERIOR

U.S. GEOLOGICAL SURVEY

\title{
Economics of Undiscovered Oil in Federal Lands on the National Petroleum Reserve, Alaska
}

by

\author{
Emil D. Attanasi
}

U. S. Geological Survey Open-File Report 03-44

January 2003

This report is preliminary and has not been reviewed for conformity to U.S. Geological Survey editorial standards and stratigraphic nomenclature.

Any use of trade, product, or firm names in this publication is for descriptive purposes only and does not imply endorsement by the U.S. Government. 


\section{CONTENTS}

Summary 1

Introduction 3

Summary of geologic assessment 5

Geologic assessment procedures 5

Characteristics of the assessed technically recoverable resources 6

Data, assumptions, and procedure for the economic analysis 12

$\begin{array}{ll}\text { Data } & 12\end{array}$

General assumptions and scope of the analysis $\quad 13$

$\begin{array}{ll}\text { Economic assumptions } & 14\end{array}$

Procedures and economic analysis $\quad 15$

Transportation, Infrastructure, and Location Assumptions 15

$\begin{array}{lr}\text { Exploration and field development costs } & 19\end{array}$

$\begin{array}{ll}\text { Exploration costs } & 21\end{array}$

$\begin{array}{ll}\text { Field development costs } & 21\end{array}$

$\begin{array}{ll}\text { Economic rationale for computations } & 24\end{array}$

$\begin{array}{ll}\text { Incremental costs: results and interpretations } & 27\end{array}$

$\begin{array}{lr}\text { Conclusions and limitations } & 28\end{array}$

$\begin{array}{ll}\text { References } & 30\end{array}$

Appendix A. Documentation of costs 38

$\begin{array}{ll}\text { Product transportation system } & 38\end{array}$

Product transportation costs $\quad 39$

$\begin{array}{ll}\text { Field development costs } & 40\end{array}$

Field design $\quad 41$

Development drilling and completion costs $\quad 42$

$\begin{array}{ll}\text { Facilities costs } & 43\end{array}$

Field production profiles $\quad 45$

Operating costs $\quad 46$

Appendix B. Tax and royalty rate assumptions 48

ILLUSTRATIONS (At end of report)

1. Location of the National Petroleum Reserve Alaska in Northern Alaska

2. Frequency-size distribution of undiscovered conventional oil accumulations associated with the mean, the $95^{\text {th }}$ and the $5^{\text {th }}$ fractile estimates of the assessed oil in the Federal part of the National Petroleum Reserve Alaska Study Area. 


\section{FIGURES CONTINUED}

3. Frequency-size distribution of undiscovered conventional gas accumulations associated with the mean, the $95^{\text {th }}$ and the $5^{\text {th }}$ fractile estimates of the assessed oil in the Federal part of the National Petroleum Reserve Alaska study area.

4. Economic sub-areas of the Federal part of the National Petroleum Reserve Alaska study area.

5. Incremental costs in 2001 dollars per barrel for finding, developing, producing, and transporting oil from undiscovered oil accumulations in the Federal part of the National Petroleum Reserve Alaska study area.

A-1. Pipeline investment costs for the regional pipeline as a function of distance.

A-2. Percentage of water in the oil production stream as a function of reservoir depletion for Alpine-type pools.

A-3. Percentage of water in the oil production stream as a function of reservoir depletion for Kuparuk-type pools.

A-4. Annual operating costs are a function of the design average daily fluid production.

\section{TABLES}

1. Mean value of undiscovered technically recoverable conventional oil, natural gas, and natural gas liquids by play in the Federal part of the National Petroleum Reserve Alaska.

2. Cumulative percentage distribution of the technically recoverable oil in the Federal portion of the NPRA study area by oil field size class.

3. Assessed mean technically recoverable oil, associated gas, and natural gas liquids in undiscovered oil accumulations in the Federal portion of the National Petroleum Reserve Alaska study area distributed by economic sub-area.

4. Incremental costs of finding, developing, producing, and transporting oil and natural gas liquids from undiscovered oil accumulations in the Federal part of the National Petroleum Reserve Alaska study area. 


\section{TABLES CONTINUED}

A-1. Distances assumed for transport of crude oil to the Trans-Alaska Pipeline System.

A-2. Estimated transport costs in dollars per barrel used in the economic evaluations from accumulation to the Trans-Alaska Pipeline System.

A-3. Selected characteristics of reservoir attributes of the Beaufortian Upper Jurassic oil plays of the National Petroleum Reserve Alaska.

A-4. Estimates of facilities investment costs in 1996 dollars per barrel of field reserves.

A-5. Accumulation production profiles assumed for new discoveries in the National Petroleum Reserve Alaska.

53

TABLE OF CONVERSION TO SI UNITS

\begin{tabular}{clc} 
multiply unit & by & to obtain metric unit \\
\hline barrel & 0.159 & cubic meter \\
cubic foot & 0.02832 & cubic meter \\
foot & 0.3048 & meter
\end{tabular}

\section{UNIT ABBREVIATIONS}

BBO ... Billions of barrels of oil

BBL ... Billions of barrels

TCF ... Trillions of cubic feet

MMBO ... Millions of barrels of oil

BCF ... Billions of cubic feet

bbl ... barrel 


\section{Economics of Undiscovered Oil in the Federal Lands of the National Petroleum Reserve, Alaska}

Emil D. Attanasi

\section{SUMMARY}

This report summarizes the economic analysis of the U.S. Geological Survey's 2002 petroleum assessment of the Federal lands in the National Petroleum Reserve Alaska (NPRA) study area. In addition to Federal lands, the study area included Native Lands within NPRA and areas underlying Alaska State waters. Estimates of technically recoverable oil in undiscovered oil accumulations in the Federal area of NPRA range from 5.9 billion barrels of oil $(\mathrm{BBO})$ to $13.2 \mathrm{BBO}$, with a mean of $9.3 \mathrm{BBO}$. The ranges in estimated volumes correspond to the 95 percent probability (that is, a 19 in 20 chance the actual volume will exceed that $95^{\text {th }}$ fractile volume) and the 5 percent probability level ( 1 in 20 chance the actual will exceed $5^{\text {th }}$ fractile volume), respectively. Estimates of technically recoverable non-associated gas in undiscovered gas accumulations range from $39.1\left(95^{\text {th }}\right.$ fractile) to $83.2\left(5^{\text {th }}\right.$ fractile) trillion cubic feet of gas (TCF) with a mean value of 59.7 TCF. Non-associated gas resources were not evaluated in the economic analysis because a market for newly discovered North Slope gas remains to be developed.

Characteristics of the assessment that are important for the economic analysis included the petroleum accumulation size-frequency distribution, location, and depth. At the mean estimate, $0.6 \mathrm{BBO}$ is in accumulations of at least 500 million barrels. Accumulation size-frequency distributions associated with the $95^{\text {th }}$ and $5^{\text {th }}$ fractiles indicate $0.2 \mathrm{BBO}$ and $1.2 \mathrm{BBO}$ were assessed in accumulations of at least 500 million barrels, respectively. At the mean quantity of oil assessed, only 37 percent of the oil was 
assigned to accumulations of at least 250 millions barrels in size. The Federal part of the study area accounted for 88 percent of the technically recoverable oil assessed and 97 percent of the gas assessed in gas accumulations

Results of the economic analysis are presented as separate cost functions associated with the mean, $95^{\text {th }}$, and $5^{\text {th }}$ fractile estimates of undiscovered technically recoverable oil. An after-tax 12 percent rate of return or hurdle rate was assumed. All calculations are in constant 2001 dollars. Transportation costs from the field to the market were included in the analysis so that prices and incremental costs are at the market rather than at the wellhead. Incremental cost functions include the full costs of finding, developing, producing, and transporting oil to market.

At a $\$ 21$ per barrel market price, $0.4 \mathrm{BBO}$ associated with the mean estimate and 2.2 $\mathrm{BBO}$ associated with the $5^{\text {th }}$ fractile estimate are economic to find, develop, produce, and transport to market. For resources associated with the $95^{\text {th }}$ fractile estimate, initial exploration costs are not compensated by the economic value of new finds until market prices reach at least $\$ 22.40$ per barrel. At a market price of $\$ 25$ per barrel, 27 percent of the technically recoverable oil assessed at the $95^{\text {th }}$ fractile (1.6 BBO), 39 percent of the oil assessed at the mean (3.7 BBO), and 47 percent of the oil assessed at the $5^{\text {th }}$ fractile (6.2 $\mathrm{BBO}$ ) is economic to find, develop, produce, and transport to market. 


\section{INTRODUCTION}

The 2002 U.S. Geological Survey assessment of the National Petroleum ReserveAlaska (NPRA, Figure 1) posits a set of scientifically based estimates of undiscovered inplace and technically recoverable quantities of oil and gas in accumulations that can be produced with conventional recovery technology. The study area included that part of the NPRA owned by the Federal government, lands underlying adjacent Alaska state waters, and native lands within the NPRA borders. Geologists assessed volumes of recoverable oil and gas that could be added to proved reserves using current technology but without reference to costs or product prices. The costs and the product prices required to transform the assessed undiscovered technically recoverable resources into producible reserves are estimated in this report.

This analysis determines that part of the assessed distribution of undiscovered accumulations that can be commercially developed at particular market prices. The analysis also estimates the incremental costs of finding, developing, producing, and transporting to market the assessed undiscovered oil. Incremental cost functions show cost-resource recovery possibilities and are not supply functions as strictly defined by economists. However, the incremental cost functions and the data that underlie the functions are often used in market supply models. The economic analysis is confined to resources in the Federal portion of the NPRA study area. This analysis does not predict the revenue or bonus payments for leases in the NPRA nor does it attempt to estimate regional or national secondary economic benefits that may result as a consequence to development of the resource. 
The economic component of the NPRA assessment is intended to place the geologic resource analysis into an economic context that is informative and easily understood by government policy makers and industry decision makers. The geologic assessment might best be described as a regional reconnaissance appraisal. The geologists attached subjective regional occurrence probabilities to hydrocarbon accumulations to capture play and prospect risk. They also formulated subjective probability distributions for reservoir attributes of such accumulations, using data from a limited number of available field studies, regional geophysical studies, knowledge about regional trends, and the postulated regional geologic history. The reservoir attribute distributions are used to predict size, depth, and production characteristics of undiscovered accumulations.

The scope of the economic analysis is also general rather than site or prospect specific. The economic analysis is limited to the evaluation of general finding costs, development costs (including the costs of primary recovery and some aspects of secondary recovery), and the costs of transporting the product to market.

\section{Undiscovered technically recoverable conventional oil and gas resources are} resources that are estimated to exist, on the basis of broad geologic knowledge and theory, in undiscovered accumulations outside of known fields. Technically recoverable resources are producible using recovery technology that is currently available but without reference to economic viability. Conventional oil and gas accumulations are discrete well-defined accumulations, typically bounded by a water contact, from which oil, gas, and natural gas liquids (NGL) can be extracted using traditional development and production practices. Accumulations assessed by geologists outside of known fields were considered for the purposes of the economic analysis as separate and discrete new fields. 
Economically recoverable resources are that part of the assessed technically recoverable resource for which the costs of finding, development, and production, including a return on capital, can be recovered by production revenues at a particular price.

The discussion first briefly reviews the geologic assessment procedures. It then summarizes characteristics of the technically recoverable resources important for understanding the economic analysis. Assumptions about markets, pricing, costs, and the technical relationships used in computing the incremental cost functions are considered. Finally, results and interpretations of the economic analysis are presented in the concluding section.

\section{SUMMARY OF GEOLOGIC ASSESSMENT}

The geologic assessment method and results are only briefly reviewed here; detail is provided in Schuenemeyer (2002, unpublished data). The commercial value of a newly discovered oil and gas field depends on its expected size, hydrocarbon type (oil or gas $^{1}$ ), depth, location, and reservoir attributes. These properties and the probability distributions used to characterize them are fundamental to understanding the results of the economic analysis.

\section{Geologic Assessment Procedures}

The geologic assessment used a play analysis paradigm. According to this paradigm (Baker and others, 1984), a play is a set of known or postulated oil and (or) gas accumulations sharing similar geologic, geographic, and temporal properties, such as source rock, migration patterns, timing, trapping mechanism, and hydrocarbon type.

\footnotetext{
${ }^{1}$ Accumulations are defined as either oil or non-associated gas on the basis of their gas-to-oil ratios. Those having at least 20,000 cubic feet of gas per barrel of crude oil were classified as non-associated gas; otherwise the accumulations were classified as oil.
} 
Individual geologists were assigned known rock units within the Study Area. Based on geologic knowledge and results of exploration throughout Northern Alaska, each geologist defined, delineated, and described the petroleum plays that were to be assessed. For each play, the assessment geologist assigned subjective probabilities to describe the play and prospect risks. They also assigned subjective probability distributions to characterize attributes of undiscovered conventional oil and gas accumulations. The minimum values of the attributes were calibrated so the smallest size of the assessed accumulations was 50 million barrels (MMBO) of oil in-place or 250 billion cubic feet of gas $(\mathrm{BCF})$ recoverable.

The geologic risk structure is modeled by assigning a play probability to each play. This probability is the likelihood that at least one accumulation of the minimum size (50 MMBO in-pace or $250 \mathrm{BCF}$ gas recoverable) occurs. In cases where the assessor was not confident of the occurrence of at least one accumulation of that threshold size, the play probability was computed as the product of the occurrence probabilities of the three play attributes of charge, trap, and timing. The geologist also assigned a prospect probability to each play that represented the probability that any randomly chosen prospect is an accumulation at least as large as the minimum size. This probability may be computed as the product of the occurrence probabilities assigned by the geologist to the prospect attributes of charge, trap, and timing. The number of accumulations (meeting the threshold size) is then the product of the number of prospects, the play probability, and the prospect probabilities. Numbers of prospects were simulated for each play realization by sampling from the subjective probability distribution specified by the assessment geologist. 
Data on reservoir attributes for plays were gathered from discoveries outside of NPRA and from analogue plays occurring elsewhere on the North Slope. Subjective reservoir attribute $^{2}$ probability distributions were elicited from the geologists. The resulting reservoir model was then applied to generate the potential sizes of undiscovered accumulations. In particular, the assessors specified subjective probability distributions for the following reservoir attributes (1) net reservoir thickness, (2) area of closure, (3) porosity, and (4) trapfill. The subjective distribution for each attribute was determined by the geologist's choice of distribution shape, the distribution's minimum value (lower truncation point $)$, the maximum value, median $\left(50^{\text {th }}\right.$ fractile) value, and the value assigned to the upper $5^{\text {th }}$ fractile ${ }^{3}$. Each assessor-specified distribution was fit to a beta or modified beta distribution that was later used as a basis for numerical simulation. The assessment geologists also formulated subjective probability distributions to characterize the number of prospects and depths of accumulations. Beta distributions were also used to describe these distributions.

In total, the assessment geologists evaluated 24 petroleum plays within NPRA and lands underlying adjacent State waters. The play descriptions with their geographic locations and geologic characteristics are summarized in Bird (2002). Most of the plays thought to occur in the study area also occur elsewhere in Northern Alaska. Supporting

\footnotetext{
${ }^{2}$ For each oil accumulation, for example, the simulated reservoir-attribute values included the following; (1) net reservoir thickness, $t$, in feet: (2) porosity, $p$, as a decimal fraction, (3) trapfill, $f$, in percent (decimal fraction), (4) hydrocarbon pore volume, $h p v$, (as a function of $p$ ) as a decimal fraction and (5) area of closure, $a c$, in thousands of acres. The assessors provided estimates of the recovery factor, $r f$, as a fraction of the in-place resources that are recoverable and the formation volume factor, $f v f$, was calculated as a function of trap depth and API gravity. Oil accumulation size, szo, in millions of barrels was calculated with the following equation: $s z o=7.758(t)(h p v)(f)(r f)(a c) /(f v f)$.

A similar approach was taken for simulating gas accumulation sizes. Schuenemeyer (2002, unpublisihed data) provides a more detailed discussion of this approach.

${ }^{3}$ Fractiles denote the fraction of area under the probability density curve to the right of the fractile value.
} 
studies were prepared by the geologists and by other assessment team members to assist in characterizing play properties with probability distributions (see Kumar and others, 2002; Verma and Bird, 2002). New information included digitally reprocessed seismic data and other new geo-chemical data, and data from new discoveries near the NRPA, and data from new discoveries outside of the NPRA in plays that occur in the NPRA.

Probability distributions describing the sizes of accumulations and numbers of accumulations and volumes of hydrocarbons for individual plays were calculated by the following simulation scheme. For each replication, $i, i=1, \ldots, N$, the play risk was evaluated. For each successful play, a variate for the risked number of accumulations in the play was computed as the product of the prospect probabilities and a random draw from the assessor's (subjective) distribution describing the number of prospects. For each realization of the play represented by the $n_{i}$ accumulations, the probability distributions representing the reservoir attributes were sampled $n_{i}$ times, thus providing a size for each accumulation (footnote 2). Ten thousand replications defined the probability distributions describing each successful play.

Pair wise dependencies of the characteristics of charge, trap, and timing were assigned between plays within the study area. The ranked dependencies (high, medium, low) were transformed into a measure of covariance between plays. Because the play assessment results are characterized by probability distributions, the covariance among plays was assessed in order to aggregate play results to higher levels (that is from the Federal to the entire study area). Aggregation procedures for the play probability distributions are provided in detail in Schuenemeyer (2002, unpublished data). 


\section{Characteristics of the Assessed Technically Recoverable Resources}

Estimates of technically recoverable oil in undiscovered accumulations in the Federal part of the NPRA range from 5.9 BBO to $13.2 \mathrm{BBO}$ with a mean of $9.3 \mathrm{BBO}$. The ranges in estimated volumes correspond to the 95 percent probability (that is, a 19 in 20 chance of occurrence) and the 5 percent probability level (1 in 20 chance), respectively. The Federal portion had been assigned about 88 percent of the oil in the study area. ${ }^{4}$ The estimates of technically recoverable non-associated gas in undiscovered gas accumulations in the Federal area ranged from 39.1 TCF to 83.2 TCF with a mean of 59.7 TCF. About 97 percent of the assessed gas in gas fields in the entire study area had been assigned to Federal areas. Table 1 presents play level and total mean estimates of oil, associated gas, associated gas NGL, non-associated gas, and non-associated NGL for the Federal area. Two plays (the Beaufortian Upper Jurassic Topset Northeast and the Beufortian Upper Jurassic Topset Northwest; Table 1) account for two-thirds of total oil assessed in the Federal area. Almost half of the total gas assessed in gas accumulations in the Federal Area was assessed in the two plays (the Brookian Topset Structural Play and the Torok Structural play; Table 1).

The depths assigned by the assessors to gas accumulations (Schuenemeyer, 2002, unpublished data) and engineering predictions of natural gas liquids (NGL) to gas ratios for gas accumulations (Verma and Bird, 2002), implied that the likelihood would be negligible that a single large gas accumulation would have a ratio sufficiently high for the field to be developed for its liquids. Technically recoverable oil accumulation sizefrequency distributions (shown in Figure 2) convey some of the economic implications of

\footnotetext{
${ }^{4}$ For the entire study area, the range is $6.7 \mathrm{BBO}$ TO $15.0 \mathrm{BB} 0$ with a mean of $10.6 \mathrm{BBO}$.
} 
the oil estimates. Few small accumulations are shown because accumulations having oil in-place of less than 50 million barrels were not considered in the assessment.

Based on the size-frequency distribution (Figure 2) associated with the mean estimate of undiscovered technically recoverable oil, only $0.6 \mathrm{BBO}$ (6.8 percent) of the assessed oil is assigned to accumulations of at least 500 million barrels (see Table 2). Similarly, accumulations of at least $500 \mathrm{MMBO}$ account for $0.2 \mathrm{BBO}$ (4 percent) and $1.2 \mathrm{BBO}(9$ percent) of the oil shown by the distributions for the 95th and 5th fractile estimates, respectively. Table 2 shows that accumulations larger than $256 \mathrm{MMBO}$ account for 3.5 $\mathrm{BBO}$ (37 percent), 1.8 BBO (32 percent), and 5.9 BBO (44 percent) of the oil associated with the mean, 95th, and 5th fractile estimates, respectively. The assessed volumes of oil are significant, but only a limited part was assigned to accumulation sizes of current economic interest.

Assessment results that are summarized in Bird and Houseknecht (2002) show that most of the oil at the play level is expected to be concentrated in plays geographically confined to the northern part of NPRA. The four plays with the largest volume of oil (Beaufortian Upper Jurassic Topset Northeast, the Beaufortian Upper Jurassic Topset Northwest, Brookian Clinoform North and Brookian Clinoform Central; Table 1), at the mean estimate account for $8.1 \mathrm{BBO}$ or 88 percent of the total oil. Overall, 7.7 $\mathrm{BBO}$ or almost 83 percent oil estimated at the mean was assigned to accumulations having depths between 5,000 and 10,000 feet, and only $0.4 \mathrm{BBO}$ or 4.4 percent was assigned to depths of less than 5,000 ft. No oil accumulations were assigned at depths greater than 15,000 feet. 
Figure 3 shows the size frequency distribution of the assessed undiscovered gas accumulations. The magnitude of the total assessed gas in gas accumulations is large. At the mean estimates, however, about one third of the gas was assigned to accumulations of at least $1.5 \mathrm{TCF}$ in size. Accumulations between $770 \mathrm{BCF}$ and $1540 \mathrm{BCF}$ in size were assigned about 27 percent of the total gas assessed. Although large volumes of gas in Northern Alaska currently have no commercial markets, the assessed magnitude and frequency- size distribution of the accumulations may be useful to those planning a future gas transportation system. The size distributions show the largest part of the assessed resources in moderate size accumulations.

The majority of the gas resources in gas accumulations are assigned to the southern and western part of NPRA. In the Federal part of the study area, the four plays with the largest volume of non-associated gas resources (the Brookian Topset Structural, the Torok Structural, the Beaufortian Clinoform, and the Brookian Clinoform Central plays; Table 1) - account for nearly two-thirds of the non-associated gas. About 43 percent of the assessed non-associated gas was assigned to depths between 10,000 and 15,000 feet and 19 percent was assigned to depths greater than 15,000 feet.

The assessors were also required to describe the expected quality of the resource, in terms of the oil gravity and contaminants of oil and gas. The average gravity for the assessed oil was about 38 degrees API. The gravity of the assessed oil is somewhat lighter than oil found near Prudhoe Bay area (Fig. 1) and those differences in oil gravity are attributed to differences in sources. There was no indication that contaminants in the assessed oil would present special problems refining (for play assessment data see Schuenemeyer, 2002, unpublished data). 
The characteristics of the technically recoverable oil most important to the economic analysis are the volumes of oil, the oil accumulation-size distribution, depth of the oil, and geographical location of the resources. Distributions in Figure 2 and supporting data (Table 2) show that most of the assessed oil was assigned to accumulations of modest size.

\section{DATA AND ECONOMIC ASSUMPTIONS}

\section{Data}

Data generated for the geologic assessment computer simulations included accumulation size (volume of recoverable oil, gas, and natural gas liquids), accumulation depth, accumulation area, net reservoir thickness, reservoir porosity, and the oil formation volume factor for oil accumulations and the gas compressibility factor, initial gas pressure, and reservoir temperature for gas accumulations. These data were used to develop expected production well recoveries for various accumulation size classes at prespecified depth intervals. The simulation data were also used to compute ratios of gas-tooil and NGL-to-natural gas by 5,000-foot depth intervals.

Cost information was drawn from previous economic studies of the Northern Alaska (Broderick, written communication, 1992, Young and Hauser, 1986, National Petroleum Council 1981a, 1981b, Thomas and others, 1993, Thomas and others, 1991, Han-Padron Associates, 1985). Additional data on recent cost trends were obtained from a variety of sources, including British Petroleum, (1996), Blount and others (1993), Broman and others (1992), Craig (2002), and written communication from the State of Alaska Pipeline Office (1998), and from J. Craig (Minerals Management Service, oral communication, 2002), and the technical literature. Drilling cost data from the Annual 
Joint Association Surveys (JAS) (American Petroleum Institute, 1997, 1999, 2000, 2001)

were used to formulate drilling cost estimates. Engineering data (Arco-Alaska, Inc, and others, 1998; Thomas and others, 1993) were used to predict the water cut of produced oil as a function of pool depletion.

\section{General Assumptions and Scope of Analysis}

The economic analysis presents estimates of the incremental costs of converting assessed undiscovered resources into additions to proved reserves. Cost functions include the costs of finding, developing, producing, and transporting to market resources in currently undiscovered accumulations. These functions are not the same as the economist's market price-supply predictions because at any given price the oil and gas industry will allocate funds over a number of provinces and supply sources in order to meet market demand at lowest costs.

An observed price-supply relationship represents the culmination of numerous supplier decisions over many projects and regions. Incremental cost functions are computed independently of activities in other areas. Furthermore, the incremental cost functions are assumed to be time independent and should not be confused with the firm supply functions that relate marginal cost to production per unit time. Because of the time-independent nature of the incremental cost functions and the absence of market demand conditions in the analysis, user costs or the opportunity costs of future resource use are not computed. However, the incremental cost functions and data that underlie the functions can be used in market supply models.

Undiscovered non-associated gas fields were not evaluated here because a viable gas transportation system does not exist in Northern Alaska, nor are the conditions yet 
established that would permit gas that is distant from the Prudhoe Bay gas conditioning plant to enter any proposed pipeline to market. Commercial gas will affect economic valuation of oil in two ways. The commercial sale of by-product gas enhances the economic worth of developing and producing a newly discovered oil accumulation. Also, gas exploration, when targeted in oil prone areas, typically accelerates the evaluation process for oil by generating information useful to those searching for oil. At this time, however, these effects on NPRA oil valuation are probably limited for the following reasons. First, the largest part of the assessed oil and gas resources in the NPRA were assigned to different geographic areas. Secondly, any positive value assigned to associated gas should incorporate the element of time for gas investment payback. The future date of the gas market development is still uncertain. Moreover, when such a market develops, the limited gas pipeline capacity available to producers outside of the Prudhoe Bay area will likely be reserved for new discoveries of gas in gas accumulations. This drives any expected commercial value of gas in oil fields (associated gas) in the NRPA to rather low levels.

In Northern Alaska, $30 \mathrm{TCF}$ of associated gas has already been discovered. It can be produced cheaply if a gas market develops. However, the US Energy Department forecast for 2020 projected that no Alaskan natural gas would be transported to the conterminous United States (Energy Information Administration, 2001). Now, associated gas produced with oil is typically stripped of its liquids and re-injected into the oil field or used as fuel on the lease. Some of the recovered natural gas liquids are now mixed with crude oil and transported through the Trans-Alaska Pipeline System (TAPS) and some are re-injected as 
a miscible fluid flood for enhanced oil recovery. This analysis assumed that associated gas is re-injected into the reservoir or used as lease fuel.

\section{Economic Assumptions}

Economic models are abstractions that characterize real economic systems, and the models are typically just detailed enough to roughly approximate the outcomes of interactions between economic agents. Only the general direction and the approximate magnitude of the reaction of the system to price or cost change can be modeled. For most models, it was assumed that the industry will not make an investment unless there is the expectation that the full operating costs, capital, and cost of capital will be recovered. For this study, it was assumed that decision makers know the values of physical and economic variables with certainty. It was also assumed that areas considered in the economic analysis were available to exploration for oil.

Costs used in this analysis were assumed to represent those prevailing in January of 2001. Calculations were in terms of constant real dollars. The discounted cash flow (DCF) analysis was specific to individual projects and ignored minimum income taxes and tax preference items that might be important from a corporate accounting stance. A 12 percent after-tax required rate of return was assumed. Federal income tax provisions included the changes made in 1993. Based on the 1986 Tax Reform Act, 30 percent of development well drilling cost is classified as tangible cost and is therefore capitalized over 7 years. Of the remaining 70 percent of drilling cost (that is, the intangible drilling cost), 30 percent is depreciated over 5 years and the remaining 70 percent is expensed immediately. 
Alaska state taxes include the severance tax, income tax, and ad valorem tax. The severance tax depends on field and well productivity (see Appendix B for details). Although the nominal state income tax rate is 9 percent, the effective tax rate is set by a complex formula based on the specific firm's production and sales. For planning purposes, State agencies use a rate of 1.4 to 3.0 percent of net income. An effective tax rate of 2.4 percent is used here. Alaska's ad valorem tax is an annual charge equivalent to 2 percent of the economic value of equipment, facilities, and pipelines. The Federal corporate tax rate used in the project analysis was 35 percent. The extreme Northeastern area of the NPRA was identified as a high potential area by the Bureau of Land Management (BLM), (Bureau of Land Management, 1998), and this area required a onesixth royalty payment on resources developed. Elsewhere in the NPRA, a one-eighth Federal royalty was assumed.

During the last thirty-five years, nominal oil prices in the conterminous United States have varied over a range from $\$ 3$ to $\$ 40$ per barrel. Discussion in this report focuses on reserve additions from new fields that might be expected with an oil price range of $\$ 18$ to $\$ 30$ per barrel in 2001 dollars. The oil price discussed is the landed US West Coast price rather than the well-head price. In the absence of gas markets, the well-head price of gas was assumed to be zero. The well-head price of natural gas liquids was assumed to be 75 percent of the per barrel price of crude oil. Although graphs may show additions to reserves for higher prices, it would unrealistic to assume that constant real costs would hold if real oil prices rise to $\$ 40$ per barrel. Experience has shown that oil and gas price increases lead to escalation in industry capital and operating costs (Kuuskraa and others, 1987). 


\section{PROCEDURES FOR THE ECONOMIC ANALYSIS}

\section{Transportation, Infrastructure and Location Assumptions}

Oil produced in Northern Alaska is shipped via the Trans-Alaska Pipeline System (TAPS) to southern Alaska for ocean tanker transport to market. The nominal capacity of the TAPS is 2.1 million barrels per day. In 1988, TAPS transported an average of 2.0 million barrels per day of oil. For 2001, just less than 1 million barrels per day of oil and natural gas liquids were transported, so that even now there is perhaps a million barrels per day of unused capacity.

The Alpine field (Figure 1) and its satellite discoveries are located near the northeast edge of the NPRA. The crude oil produced at Alpine is transported in a small pipeline to the Kuparuk River field (adjacent to the Prudhoe Bay field) where it is, in turn, transported to the Trans-Alaska Pipeline System's Pump Station 1. Alpine and its satellite discoveries are expected to fully utilize the small pipeline from the edge of NPRA to the Kuparuk River field for the next decade, so it will not be immediately available for transporting oil from new NPRA discoveries. For new oil discoveries in northern NPRA, it was assumed that a 24-inch regional pipeline would be built from the interior of NPRA to the Kuparuk River field, the oil would be transported to TAPS Pump Station 1, located within the Prudhoe Bay field (Figure 4).

For the purpose of estimating likely product transport costs, the NPRA was partitioned into eight sub areas (Figure 4). Geologists were asked to allocate assessed oil and nonassociated gas resources to these subareas. New discoveries within each sub area are assumed to have similar transportation costs. Table 3 shows the subarea allocations of the mean estimates of oil in oil accumulations and gas in gas accumulations. At the mean 
estimate, $85 \%$ of the assessed oil in oil accumulations was assigned to subareas 110,120 , and 130; with two-thirds of the total oil assigned to sub-areas 110 and 120 . With almost all of the oil concentrated in the northern set of sub-areas, it was assumed that a 24 inch diameter regional pipeline would be built in stages and would roughly bisect the north/south width of the prospective area of sub-areas 110, 120, and 130. For oil assigned to subareas 210,220 , and 230 , the transportation cost computations assumed that a smaller diameter (20 inch) regional pipeline would be built that would roughly bisect those areas (north of the foothills) to carry oil directly eastward to TAPS Pump Station 2 (Figure 4).

Distances from the designated centroid points within the sub-areas were used for estimating pipeline materials and construction investment cost. A regulated common carrier pipeline business entity is assumed to build and operate the regional pipelines to the TAPS. Pipeline tariff charges were set to meet all operating costs and taxes, and to assure investors a 12 percent after-tax return on investment. The liquid flow capacity for the 24 inch diameter pipeline was assumed to be at least 500,000 barrels per day (HanPadron Associates, 1987) and the capacity for the 20 inch pipeline was assumed to be 300,000 barrels per day (Han-Padron Associates, 1987). Pipeline investment cost functions originally presented in Young and Hauser (1986), and later updated by Broderick (written communication, 1992), were further adjusted to reflect the continuing decline in pipeline costs experienced on the Northern Alaska. Estimates of costs considered typical of the Prudhoe Bay area were inflated by 30 percent to account for the remoteness and special rules for the NPRA. Distances that were assumed are provided in Appendix A. 
Other than the rough allocations made by the geologists to the sub-areas in Figure 4, there was no spatial dimension to the assessment. Unless the assessment geologist provided other information, accumulations were assumed uniformly distributed within the prospective area of each block. Given that assumption, the average cost to transport the oil to TAPS is calculated in two stages. First, it was assumed that 12 inch or 16 inch lateral pipelines were built from the border of the accumulation to the regional pipeline, and that the oil is transported eastward by regional pipeline system. The regional pipeline from Northern NPRA, was assumed to use the Kuparuk field pipeline system for transport to Pump Station 1 where an additional tariff of $\$ 0.21$ per barrel was charged for transport to TAPS. The parallel regional pipeline from the sub-areas 210, 220, and 230 was assumed connected to TAPs Pump Station 2 (see figure 4).

The TAPS tariff rate and marine transport rate to market are projected semi-annually by the Alaska Department of Revenue. The marine transport rate represents the cost weighted by projected sales volumes of transporting crude oil from the Port of Valdez in Southern Alaska to a set of destinations the include the US lower 48 West Coast, the Far East, and the US mid-continent region. These rates are projected on an annual basis to 2020 in nominal dollars (Alaska Department of Revenue, 2001). Assuming a 3 percent inflation rate, in constant real 2001 dollars, the average projected TAPS tariff for the period is $\$ 2.88$ per barrel and similarly, the marine transport cost is $\$ 1.43$ per barrel for a total rate of $\$ 4.21$ per barrel.

\section{Exploration and field development costs}

Exploration and field development methods in the Northern Alaska differ from those of the lower 48 States. Wildcat drilling occurs in winter when temporary ice roads, ice pads, 
and ice airstrips are constructed to support drilling activities. Seasonal instability of the permafrost requires construction of gravel pads to support permanent production wells and facilities. Production wells are drilled directionally from the pads to target distant locations at depth. Gravel drilling pads can typically support as many as 40 well collars spaced at 10 foot intervals along with production equipment. Sidetrack and multilateral drilling of two or more wells using a single well collar enables the maximum utilization of individual drilling pads. The remoteness of the targets, the climate, and the absence of infrastructure impose high initial exploration and development costs on prospects.

For a stand-alone field development, produced oil is processed at the field's central processing facility and then transported from the periphery of the field to the TAPS. Because commercial accumulations are large and they provide a substantial payoff in terms of the volumes of oil that incremental increases in recovery can yield, operators try to introduce technological innovations quickly. For example, the application of extended reach drilling has allowed access to distant reaches of the reservoir, sometimes allowing satellite field development from existing drill pads. For this study, it was assumed that any offshore accumulations within the NPRA that occur beneath the lagoonal areas between the shoreline and barrier islands can be developed from onshore drilling pads.

The costs estimated in this study are generic and they only account in a very general way for the remoteness and the special regulations (such as the prohibition of permanent haul roads imposed on operations in the NPRA). Baseline costs were generally calibrated for Prudhoe Bay area operations and increased by 30 percent to account for the higher costs of operation in the NPRA. Cost estimates are quite uncertain but this broad 
range of uncertainty will undoubtedly narrow as industry gains experience in developing resources in the NPRA.

Exploration costs

Exploration effort leading to new field discoveries is represented by the drilling of wildcat wells. Exploration costs are accounted for after the lease is acquired. Nondrilling exploration expenditures (exclusive of lease bonuses) were assumed to amount to no more than 50 percent of the drilling cost (Energy and Environmental Analysis, Inc., 1993). Non-drilling exploration expenditures include geologic and geophysical data collection after lease acquisition, scouting costs, and overhead charges associated with land acquisition. Wildcat well drilling costs were assumed to be twice the cost of drilling production wells in the NPRA. ${ }^{5}$ New field exploration was evaluated in increments of 20 wildcat wells and a minimum cost of 10 million dollars per well was assumed for the first twenty wildcat wells drilled. Actual exploration costs, however, will depend on sitespecific characteristics of each prospect. For this study, generic costs were used because play analysis does not provide specific locations.

Field development costs

The continuing reduction in capital and operating costs for new discoveries on the Northern Alaska has been substantial (Williams, 2001a, 2001b, 2001c, Thomas and others, 1993, Harris, 1987a, 1987b). The two principal field development costs categories are facilities costs and well costs (drilling and completion of production and injection wells). Design and cost data are presented in Appendix A.

\footnotetext{
${ }^{5}$ For example, a conventional development well drilled to a depth of 7,500 feet in the NPRA is estimated to cost 3.2 million dollars. Total costs for a comparable wildcat well, including non-drilling costs that amount to 50 percent of drilling cost, are 9.6 million dollars.
} 
Field drilling costs were based on the number of wells required to develop fields and the cost per well. Per well drilling cost estimates were assumed to represent long-run future costs, and they were estimated using data from the Joint Association Survey (American Petroleum Institute, 1998-2001). The estimated Prudhoe Bay area drilling costs were increased by 30 percent to compensate for a lack of infrastructure and(or) special regulations associated with the NPRA. Estimated drilling and completion costs per conventional development well were as follows: (1) $\$ 2.5$ million for depths to 5,000 feet, (2) $\$ 3.2$ million for 5,000 feet to 10,000 feet depths, and (3) $\$ 5.1$ million for 10,000 feet to 15,000 feet depth. No oil was assessed at depths greater than 15,000 feet. In the northern NPRA economic sub-areas, nearly all of the assessed oil is from the Upper Jurassic Beaufortian Play, Northeast and Northwest (Table 1). It was assumed that fields in these areas are developed with horizontal wells. Appendix A provides more detail on the drilling cost analysis.

The number of wells required to develop a discovery depends on well productivity. Expected values for well productivity were calculated using the play level reservoir attribute values associated with each simulated accumulation. For each accumulation size and depth category, average well productivity based on an assumed production well spacing was calculated as the weighted average of the well productivity of the predicted accumulations occurring in that classification. Well productivity estimates varied substantially across different depth intervals and within the same accumulation-size category, reflecting broad variations in reservoir quality of the plays occurring in the depth interval. Conventional production wells were assumed drilled on 160 acre spacing and horizontal production wells on 320 acre spacing. For each conventional production 
well, it was assumed that 0.4 injection wells (water or gas) would also be drilled (National Petroleum Council, 1981a, Young and Hauser, 1986) and for horizontal wells one injector would be drilled for each production well.

Facilities include drill pads, flow lines from drilling sites, a central processing unit, and infrastructure required for workers. Facilities design and costs depend on peak fluid flow rates and ultimately on the field size. This cost category has had the most dramatic reduction during the last decade, as operators have introduced new field designs and systems in an effort to minimize costs. The application of technology that resulted in extended reach drilling and multilateral production wells has reduced the number and size of drill pads needed for field development (Williams, 2001a). Facilities investment cost levels calibrated for the Prudhoe Bay area were increased by 30 percent to compensate for the special provisions attached to field development in the NPRA.

Development of new discoveries on a satellite or facilities cost-sharing basis can reduce facilities costs and reduce the time to production. Without site-specific information, it would be difficult to defend a blanket assumption that all of the smaller accumulations that were assessed could be developed on a satellite basis. The nature of the geologic assessment is general and even the sub-areas to which the geologist made the allocations of the play resources are large. Table 3 shows the allocations of oil accumulations and resources to the individual sub-areas. Actual savings are site-specific because certain facilities costs such as drill pads, internal roads, and product transportation are location dependent.

It was assumed that facilities sharing could, on average, result in a 30 percent reduction in facilities investment costs (Thomas and others, 1993) for sub-areas 110 and 
120. In this type of facilities sharing arrangement, production from the smaller field is sent to the central processing unit of the larger field, with the liquids product then taken by a sales pipeline and the gas and water returned to the small field for injection ${ }^{6}$. For this study, facilities-sharing was limited to accumulations smaller than 130 million barrels but larger than 30 million barrels in the 110 and 120 sub-areas only. Facilitiessharing in other economic sub-areas is less likely because of the small numbers of assessed fields, the small volumes of undiscovered oil, and the probability of greater distances between fields.

Field operating costs include labor, supervision, overhead and administration, communications, catering, supplies, consumables, well service and work-overs, facilities maintenance and insurance, and transportation. Some costs, such as well work-over costs have declined because of the introduction of new materials such as coiled tubing (Williams, 2001a, 2001c, 2001d). For this study, annual field operating costs were estimated as a function of hydrocarbon and water fluid volumes (Appendix A). These volumes were projected annually using field production forecasts and water cut functions based on historical data from the Kuparuk reservoir (Thomas and others, 1991) and the projected water cut/oil depletion for the Alpine reservoir (Arco Alaska, Inc, and others, 1998). The water cut increases as the reservoir is depleted, thereby increasing the per barrel cost of oil.

\footnotetext{
${ }^{6}$ More dramatic investment savings of perhaps 75 percent of investment costs are possible when a satellite accumulation uses a larger field's drill pads, pipelines, and infrastructure. In that case the accumulations must be very close geographically. For the alternative case where the product is sent to another field's central processing facility, the distances separating the accumulations can sometimes be up to 15 miles.
} 


\section{Economic rationale for computations}

Accumulation size, depth, regional costs, and co-product ratios determine whether a field will be commercially developable. A new accumulation is commercially developable if the after-tax net present value of its development is greater than zero. For this study, the algorithm that calculated incremental costs used the predicted size and depth distribution of undiscovered fields (at the sub-area level) to compute quantities of resources that are commercially developable at various prices. To compute finding costs, the geologic assessment is coupled with a finding rate model (Attanasi and Bird, 1996, Attanasi, 1999) to forecast the size and depth distribution of new discoveries from increments of wildcat drilling. These forecasts drive the economic field development and production process model to determine the aggregate value of new discoveries and to determine the number of successive increments of wildcat wells that should be drilled.

The commercial value of developing a representative field for a specific field size class (Figure 2) and depth category is determined by a discounted cash-flow (DCF) analysis at a given price. The net after-tax cash flow consists of revenues from the production of oil less the operating costs, capital costs in the year incurred, and all taxes. All new discoveries of a particular size and depth category are assumed developed if the representative field is found to be commercially developable (that is, if the after-tax DCF is greater than zero, where the discount rate of 12 percent represents the cost of capital and the industry's required return). It is assumed that when operator income declines to the sum of the direct operating costs and the operator's production-related taxes, then the economic limit rate is reached and field production stops. 
Newly discovered commercially developable fields are aggregated to provide an estimate of potential reserves from undiscovered fields for a given price and a required rate of return. The results from this procedure do not imply that every predicted discovery determined to be commercially developable is worth exploring for.

The basis for the estimates of recoverable undiscovered petroleum as a function of price is that the incremental units of exploration, development, and production effort will not occur unless the expected revenues from the eventual production will cover the incremental costs, including a normal return on the incremental investment. Exploration is assumed to continue until the incremental cost of drilling wildcat wells is equal to or greater than the net present value of the cost of the commercially developed fields discovered by the last increment of wildcat wells. For the last increment of oil and gas produced from a field, operating costs (including production related taxes) per barrel of oil equivalent are equal to net well-head price.

These two assumptions together imply that for the commercially developable resources discovered by the last economic increment of wildcat wells (that is, for those reserves found, developed and produced at the economic margin), the sum of finding costs and development and production costs per barrel equals the well-head price. These costs are called the marginal finding costs and the marginal development and production costs.

The marginal finding costs are calculated by dividing the cost of the last increment of wildcat wells (which is approximately equal to the sum of the after-tax net present value of all commercially developable fields discovered in that last increment of exploration) by the volume of economic resources discovered by the last increment of exploration. 
Marginal development and production cost per barrel (for the economic resources discovered in that last increment of exploration) are calculated by subtracting the marginal finding costs from the well-head price.

Finding rate functions provide the critical link between field development costs and exploration costs. For this study, the size, depth, and number of undiscovered accumulations were computed from the geologic assessment data. However, finding rate functions determine the ordering of new discoveries and the rates at which new accumulations are found as a function of cumulative wildcats drilled in a particular depth interval. A consistent set of finding rate coefficients could not be calculated for Northern Alaska but a procedure for obtaining default coefficients is described in Attanasi and Bird (1996). Allocations of wildcat wells by depth interval were made in such a way that the after-tax net present value of the oil fields discovered was maximized for each increment of wildcat wells evaluated.

\section{INCREMENTAL COSTS: RESULTS AND INTERPRETATIONS}

The full costs of bringing undiscovered oil resources to market include finding, development, production, and, in the case of Northern Alaska, transportation costs. Incremental costs are linked to development, production, and transportation cost by finding rate functions that predict the discovery size distributions generated by increments of wildcat wells (Attanasi and Bird, 1996). For this study, computations were based on successive increments of 20 wildcat wells. Figure 5 presents the incremental cost functions for crude oil for the Federal NPRA based on the undiscovered accumulation size distributions associated with the 95th fractile, the mean, and 5th fractile estimates. Table 4 summarizes the sub-area estimates of incremental costs, expected reserve additions, and 
finding costs. Along with crude oil, the Table 4 also shows the associated gas liquids in developable oil discoveries.

Figure 5 shows the differences in incremental costs that result from the different accumulation frequency-size distributions associated with estimates of the 95th fractile, the mean, and 5th fractile of the NPRA oil distribution. As noted earlier, most of the differences in the distributions are in the numbers of fields rather than the sizes. The preponderance of fields is smaller than 250 million barrels. Small fields are typically more costly to find and once found they may not even be commercially developable. The threshold prices at which wildcat drilling and development starts are $\$ 22.40$ per barrel for the 95th fractile distribution, $\$ 21$ per barrel for the distribution associated with the mean, and $\$ 20.10$ per barrel for the distribution associated with the 5th fractile estimate. The incremental cost functions show large additions to reserves as prices increase beyond the trigger prices that allow marginal fields (less than 500 million barrels, see Table 2) to be commercially developed.

For the mean and $5^{\text {th }}$ fractile distributions at $\$ 21$ per barrel, $0.43 \mathrm{BBO}$ and $2.23 \mathrm{BBO}$ are economic to find, develop, produce, and transport to markets. This amounts to 5 percent and 17 percent of the technically recoverable oil assessed at the mean and $5^{\text {th }}$ fractile. At $\$ 30$ per barrel, 60 percent of the assessed technically recoverable oil for the mean is economic, 69 percent for the 5th fractile is economic, and 49 percent of the assessed oil for the 95 th fractile is economic. Table 4 shows that sub-areas 110 and 120 dominate the estimated economically recoverable oil.

\section{CONCLUSIONS AND LIMITATIONS}


Technically recoverable oil resources assessed in the Federal part of the NPRA study area at the $95^{\text {th }}$ and $5^{\text {th }}$ percentile are 5.9 and $13.2 \mathrm{BBO}$, respectively. The mean technically recoverable oil amounted to $9.3 \mathrm{BBO}$, which represented about 88 percent of the assessed technically recoverable oil in the total study area that included the Federal part of the NPRA, native lands within the NPRA, and lands underlying Alaska State waters. The underlying undiscovered accumulation size distributions showed that less than 40 percent of the assessed oil was assigned to accumulations having at least 250 million barrels of recoverable oil.

Because of the relatively small sizes of the accumulations and the absence of infrastructure, the commercial development of discoveries will be challenging. At a market price of $\$ 25$ per barrel, the range of economically recoverable oil is from 1.6 $\mathrm{BBO}$ to $6.2 \mathrm{BBO}$ with a mean of $3.7 \mathrm{BBO}$. The regional play assessment provided only limited spatial information about locations of prospects, so the possibility remains that small fields might be developed using drill pads and infrastructure of the larger fields. Moreover, particular operators may have special knowledge or experience that could significantly enhance the finding efficiencies assumed in this study. Whereas the uncertainty attached to the geologic assessment is evident by the differing quantities of oil at alternative probabilities, there are also significant un-quantified uncertainties about the economic evaluation by virtue of the many assumptions made and the very limited empirical data on oil resource development in the NPRA. 
Reference list

Advanced Resources International, 2001, Review of resource distribution and drilling and operation costs, Alaska Oil Supply for the Oil and Gas Supply Model FE 30 Support Contract: Contract No: DE-AC01-99FE65607, 24p.

Alaska Department of Revenue, 2001, Fall 2001 Revenue Source Book: Anchorage, Alaska,

American Petroleum Institute, 2002, American Petroleum Institute, Basic Petroleum Data Book, vol. 32, no. 1. Washington, D.C.

American Petroleum Institute, 2001, 2000 Joint Association Survey of Drilling Costs:

American Petroleum Institute, Washington, D.C., 107 p.

American Petroleum Institute, 2000, 1999, Joint Association Survey of Drilling Costs: American Petroleum Institute, Washington, D. C., 107 p.

American Petroleum Institute, 1999, 1998 Joint Association Survey of Drilling Costs: American Petroleum Institute, Washington, D.C., 108 p.

American Petroleum Institute, 1997, 1996 Joint Association Survey of Drilling Costs: American Petroleum Institute, Washington, D.C., 98 p.

Arco Alaska Inc., Anadarko Petroleum Corp., and Union Texas Petroleum LLC, 1998, Alpine written testimony, Alpine Pool Rules Hearing, Alaska Oil and Gas Conservation Commission, December 3, 1998, Anchorage.

Attanasi, E. D. 1999, Economics of undiscovered oil in the 1002 Area of the Arctic National Wildlife Refuge, in; The Oil and Gas Resource Potential of the Arctic National Wildlife Refuge 1002 Area, Alaska; U.S. Geological Survey Open File Report 98-34. CD-ROM.

Attanasi, E.D., and Bird, K.J, 1996, Economics and undiscovered conventional oil and gas accumulations in the 1995 National Assessment of U.S. Oil and Gas Resources; Alaska: U.S. Geological Survey Open-File Report 95-75J, 48p.

Baker, R. A., Gehman, H. M., James, W. R., and White, D. A., 1984, Geologic field number, and size assessments of oil an gas plays, AAPG Bulletin, v. 68, n. 4, p. 426-437.

Bird, K.J. and Houseknecht, D.W., 2002, U.S. Geological Survey 2002 petroleum resource assessment of the National Petroleum Reserve in Alaska (NPRA): U.S. Geological Survey Fact Sheet FS 045-02, 4p. 
Bird, K.J, 2002, Oil and Gas Potential of the National Petroleum Reserve, Alaska, paper presented at American Association of Petroleum Geologist Pacific Section Meeting, May 22, 2002, available from K. Birsd, USGS, Menlo Park, California.

Blount, C. G., Ward, S. L., Hightower, C. M., and Walker, E. J., 1993, Emerging coiledtubing applications at Prudhoe Bay, Alaska: Society of Petroleum Engineers, Preprint 26086, Presented at Western Regional Meeting, Anchorage, 26-28 May 1993, p. 581585.

British Petroleum Exploration (Alaska), 1996, Northstar Development Project: Conceptual Engineering Report, Anchorage, Alaska: Report submitted for evaluation to the Alaska Department of Natural Resources.

Broderick, J., 1992, Arctic National Wildlife Refuge 1002 Area Oil and Gas Analysis, Bureau of Land Management (DRAFT), written personal communication.

Broman, W. H., Stagg,T. O., and Rosenzweig, J., J. 1992, Horizontal-well performance at Prudhoe Bay: Journal of Petroleum Technology, vol. 44, October 1992, p. 1074-1080.

Bureau of Land Management, 1998, Northeast National Petroleum Reserve Alaska, Final Integrated Activity Plan/Environmental Impact Statement, Volumes I and II.

Craig, J., 2002, Appendix D-1: Economic analysis of the development alternatives for the Liberty prospect, Beaufort Sea, Alaska, in Liberty Development Production Plan, Draft Environmental Impact Statement, OCS EIS/EA MMS 2001-001, Minerals Management Service Alaska, Vols. I, II, III

Energy and Environmental Analysis, Inc., 1993, Guide to the Hydrocarbon Supply Model: 1993 Update, Gas Research Institute Contract No. 5090-800-199, GRI-93/0454, $272 p$.

Energy Information Administration, 2001a, Annual Energy Outlook, 2002 with projections to 2020: U.S. Department of Energy, DOE/EIA-03083(2001), 255p.

Energy Information Administration, 2001b, Costs and indices of domestic oil and gas field equipment and production operations 2000: U. S. Department of Energy, DOE/EIA0185(2001), http://www.eia.doe.gov/oil_gas/natural_gas/data_publications/cost_indices/c_i.html.

Gautier, D. L., Dolton, G. L., Takahashi, K. I., and Varnes, K. L., eds., 1995, 1995 National Assessment of United States oil and gas resources; Results, methodology, and supporting data: U.S. Geological Survey Digital Data Series 30. CD-ROM

Han-Padron Associates, 1985, Beaufort Sea petroleum technology assessment: Contract report for Minerals Management Service; Technical Report 112, chapter 7-Transportation technology assessment, [Available from the National Technical Information Service, Springfield VA, 22161], 54p. 
Harris, M., 1987a, Endicott benefits from lessons learned: Alaska Construction, October 1987, p.15-16.

Harris, M., 1987b, Oil industry in transition: Alaska activity on the rebound: Alaska Construction, October 1987, p. 10-14.

Kumar, N., Bird, K.J., Nelson, P.H., Grow, J.A., and Evans, K.R., 2002, A digital atlas of hydrocarbon accumulations within and adjacent to the National Petroleum ReserveAlaska (NPRA): U. S. Geological Survey Open-File Report 02-71, 81p. (http://geopubs.wr.usgs.gov/open-file/of02-071/).

Kuuskraa, V. A., Morra, F. Jr. and Godec, M.L., 1987, Importance of cost/price relationships for least-cost oil and gas resources: Society of Petroleum Engineers Paper 16290, Proceedings of 1987 Hydrocarbon Economics and Evaluation Symposium, Dallas, p. 25-42.

National Petroleum Council, 1981a, U.S. Arctic Oil and Gas: National Petroleum Council, Washington D.C., December 1981, 286p

National Petroleum Council, 1981b, Working papers of the Production Task Group of the National Petroleum Council's Committee on Arctic Oil and Gas Resources: National Petroleum Council, Washington, D.C., 372 p.

Schuenemeyer, J. H, 2002, Methodology and results for the assessment of oil and gas resources, National Petroleum Reserve Alaska: unpublished data, available from K. Bird, US Geological Survey, Menlo Park, California.

Thomas, C. P., Doughty, T. C., Faulder, D. D., Harrision, W. E., Irving, J. S., Jamison, H. C., and White, G. J., 1991, Alaska oil and gas energy wealth or vanishing opportunity:

E.G. and G, Idaho, Inc., Idaho Falls, Ida., DOE/ID/01570-H1, 279p.

Thomas, C., Allaire, P., Doughty, T. C., Faulder, D. D., Irving, J. S., Jamison, H. C., and White, G. J.,1993, Alaska North Slope National Energy Strategy Initiative, Analysis of five undeveloped fields: U.S. Department of Energy, Bartlesville, Okla. DOE/ID/01570T164, (DE93000142), 348p.

Verma, M., and Bird, K. J., 2002 , Role of reservoir engineering in the assessment of undiscovered oil and gas resources in the Natonal Petroleum Reserve, Alaska, paper presented at American Association of Petroleum Geologist Pacific Section Meeting, May 22, 2002, available from M. Verma, USGS, Denver Colorado.

Williams, Robert, 2001a, New era dawning for Alaska North Slope: Oil and Gas Journal, v. 99 , no. 32. p. 58-66. 
Williams Robert, 2001b, Phillips makes own mark on North Slope with Alpine start-up, NPR-A strikes: Oil and Gas Journal, v. 99, n. 32, p. 68-73.

Williams, Robert, 2001c, BP rejuvenating North Slope outlook with new technology, strategies: Oil and Gas Journal, v. 99, n. 32, p. 74-77.

Williams, Bob, 2001d, Operator unlocking North Slope's vicious oil commerciality: Oil and Gas Journal, v. 99, n. 32, p. 36-40.

Young, J. H., and Hauser, W. S., 1986, Economics of oil and gas production from the Arctic Refuge (ANWR), Anchorage, Alaska: U.S. Bureau of Land Management, Alaska State Office, Anchorage, 101p. 
Table 1. Mean value of undiscovered technically recoverable conventional oil, natural gas, and natural gas liquids (NGL) in the Federal part of the National Petroleum Reserve Alaska study area by play as of May $2002(\mathrm{BBO}=$ billion barrels of oil, $\mathrm{TCF}=$ trillion cubic feet of gas, $\mathrm{BBL}=$ billion barrels of natural gas liquids).

OIL ACCUMULATIONS

GAS ACCUMULATIONS

OIL GAS NGL GAS NGL

\begin{tabular}{|l|c|c|c|c|c|}
\hline \multicolumn{1}{|c|}{ Play } & (BBO) & (TCF) & (BBL) & (TCF) & (BBL) \\
\hline Brookian Topset & 0.206 & 0.130 & 0.003 & 0.177 & 0.002 \\
\hline Brookian Clinoform North & 1.045 & 0.890 & 0.009 & 0.553 & 0.007 \\
\hline Brookian Clinoform Central & 0.953 & 1.206 & 0.118 & 5.081 & 0.111 \\
\hline Brookian Clinoform South-Shallow & 0.508 & 0.362 & 0.048 & 2.405 & 0.048 \\
\hline Brookian Clinoform South-Deep & 0.000 & 0.000 & 0.111 & 3.788 & 0.111 \\
\hline Beaufortian Cretaceous Topset North & 0.077 & 0.059 & 0.006 & 0.316 & 0.005 \\
\hline Beaufortian Cretaceous Topset South & 0.000 & 0.000 & 0.047 & 2.002 & 0.044 \\
\hline $\begin{array}{l}\text { Beaufortian Upper Jurassic Topset } \\
\text { Northeast }\end{array}$ & 4.762 & 5.808 & 0.000 & 0.000 & 0.000 \\
\hline $\begin{array}{l}\text { Beaufortian Upper Jurassic Topset } \\
\text { Southeast }\end{array}$ & 0.000 & 0.000 & 0.124 & 5.137 & 0.124 \\
\hline $\begin{array}{l}\text { Beaufortian Upper Jurassic Topset } \\
\text { Northwest }\end{array}$ & 1.395 & 1.690 & 0.000 & 0.000 & 0.000 \\
\hline $\begin{array}{l}\text { Beaufortian Upper Jurassic Topset } \\
\text { Southwest }\end{array}$ & 0.000 & 0.000 & 0.126 & 4.854 & 0.117 \\
\hline Beaufortian Lower Jurassic Topset & 0.067 & 0.002 & 0.014 & 0.634 & 0.011 \\
\hline Beaufortian Clinoform & 0.008 & 0.010 & 0.019 & 0.773 & 0.018 \\
\hline Brookian Topset Structural & 0.136 & 0.059 & 0.118 & 10.500 & 0.117 \\
\hline Torok Structural & 0.034 & 0.019 & 0.264 & 17.726 & 0.261 \\
\hline Ellesmerian Structural & 0.000 & 0.000 & 0.078 & 1.970 & 0.077 \\
\hline Thrust Belt & 0.006 & 0.004 & 0.049 & 1.505 & 0.049 \\
\hline Ellesmerian Ivishak & 0.077 & 0.051 & 0.002 & 0.096 & 0.002 \\
\hline Ellesmerian Echooka North & 0.006 & 0.004 & 0.000 & 0.006 & 0.000 \\
\hline Ellesmerian Echooka South & 0.000 & 0.000 & 0.014 & 0.480 & 0.013 \\
\hline Ellesmerian Lisburne North & 0.026 & 0.019 & 0.000 & 0.020 & 0.000 \\
\hline Ellesmerian Lisburne South & 0.000 & 0.000 & 0.019 & 0.627 & 0.018 \\
\hline Ellesmerian Endicott North & 0.002 & 0.001 & 0.000 & 0.001 & 0.000 \\
\hline Ellesmerian Endicott South & 0.000 & 0.000 & 0.039 & 1.019 & 0.037 \\
\hline TOTAL & 9.306 & 10.314 & 1.207 & 59.668 & 1.172 \\
\hline
\end{tabular}


Table 2. Cumulative percentage distribution of estimated technically recoverable oil; Federal lands of the National Petroleum Reserve Alaska study area by oil field size class.

\begin{tabular}{|c|r|r|r|}
\hline Oil Field & \multicolumn{4}{|c|}{ Cumulative percent of total oil } \\
\hline Size Class & \multicolumn{1}{|c|}{ F95 } & \multicolumn{1}{c|}{ Mean } & \multicolumn{1}{|c|}{ F05 } \\
\hline (MMB0) & & & \\
\hline $2048-4096$ & 0.0 & 0.0 & 0.0 \\
\hline $1024-2048$ & 0.0 & 0.3 & 0.0 \\
\hline $512-1024$ & 3.7 & 6.8 & 9.1 \\
\hline $256-512$ & 31.6 & 37.3 & 44.3 \\
\hline $128-256$ & 65.0 & 71.3 & 74.8 \\
\hline $64-128$ & 88.0 & 90.4 & 92.1 \\
\hline $32-64$ & 97.5 & 98.1 & 98.6 \\
\hline $16-32$ & 100.0 & 100.0 & 100.0 \\
\hline $8-16$ & 100.0 & 100.0 & 100.0 \\
\hline
\end{tabular}


Table 3. Assessed mean technically recoverable oil, associated gas, and natural gas liquids (NGL) in undiscovered oil accumulations on Federal lands of the National Petroleum Reserve Alaska study area distributed by economic sub-area. $(\mathrm{BBO}=$ billion barrels of oil, $\mathrm{TCF}=$ trillion cubic feet gas, $\mathrm{BBL}=$ billion barrels of natural gas liquids, assoc. $=$ associated gas).

\begin{tabular}{|c|c|c|c|c|c|c|c|c|c|}
\hline & \multicolumn{2}{|l|}{$95^{\text {th }}$ fractile oil } & & Mean & & \multicolumn{3}{|l|}{$5^{\text {th }}$ fractile oil } & \\
\hline Sub-area & oil & assoc. gas & NGL & oil & assoc. gas & NGL & oil & assoc. gas & NGL \\
\hline & BBO & TCF & BBL & BBO & TCF & BBL & BBO & TCF & BBL \\
\hline 110 & 2.13 & 2.44 & 0.04 & 3.36 & 3.85 & 0.07 & 4.83 & 5.59 & 0.10 \\
\hline 120 & 2.00 & 2.26 & 0.04 & 3.15 & 3.57 & 0.07 & 4.47 & 5.13 & 0.09 \\
\hline 130 & 0.88 & 1.01 & 0.02 & 1.38 & 1.58 & 0.03 & 1.90 & 2.18 & 0.04 \\
\hline 210 & 0.39 & 0.43 & 0.01 & 0.64 & 0.69 & 0.01 & 0.90 & 0.98 & 0.02 \\
\hline 220 & 0.32 & 0.29 & 0.01 & 0.54 & 0.48 & 0.01 & 0.79 & 0.69 & 0.02 \\
\hline 230 & 0.14 & 0.10 & 0.00 & 0.22 & 0.16 & 0.00 & 0.30 & 0.22 & 0.00 \\
\hline 320 & 0.00 & 0.00 & 0.00 & 0.01 & 0.00 & 0.00 & 0.01 & 0.01 & 0.00 \\
\hline 330 & 0.01 & 0.00 & 0.00 & 0.01 & 0.01 & 0.00 & 0.02 & 0.01 & 0.00 \\
\hline
\end{tabular}


Table 4. Incremental costs of finding, developing, producing, and transporting oil and natural gas liquids (NGL) from undiscovered oil accumulations in the Federal part of the National Petroleum Reserve Alaska study area and the estimated finding costs corresponding $95^{\text {th }}$ and $5^{\text {th }}$ fractile estimate and mean estimate of technically recoverable oil $(\mathrm{BB} 0=$ billion barrels of oil, BBL-billion barrels of NGL).

\begin{tabular}{|c|c|c|c|c|c|c|c|c|c|c|}
\hline & & $\mathrm{F}_{95}$ & & & Mear & & & & $\mathrm{F}_{5}$ & \\
\hline SUBAREA & COST & OIL & NGL & FIND/COST & OIL & NGL & FIND/COST & oil & NGL & FIND/COST \\
\hline & $\$ / b b l$ & $\mathrm{BBO}$ & BBL & \$ / BBL & $\mathrm{BBO}$ & BBL & \$/BBL & $\mathrm{BBO}$ & BBL & \$ / BBL \\
\hline 110 & 18 & 0.00 & 0.00 & 0.00 & 0.00 & 0.00 & 0.00 & 0.00 & 0.00 & 0.00 \\
\hline & 21 & 0.00 & 0.00 & 0.00 & 0.43 & 0.01 & 0.39 & 1.18 & 0.02 & 0.35 \\
\hline & 24 & 0.66 & 0.01 & 0.60 & 1.48 & 0.03 & 0.50 & 2.82 & 0.06 & 0.71 \\
\hline & 27 & 1.20 & 0.03 & 0.97 & 2.22 & 0.05 & 1.05 & 3.73 & 0.08 & 0.98 \\
\hline & 30 & 1.35 & 0.03 & 1.26 & 2.52 & 0.05 & 1.33 & 3.90 & 0.08 & 1.24 \\
\hline & 33 & 1.54 & 0.03 & 2.09 & 2.63 & 0.06 & 1.71 & 4.10 & 0.09 & 2.09 \\
\hline & 36 & 1.61 & 0.03 & 2.70 & 2.71 & 0.06 & 2.22 & 4.16 & 0.09 & 2.70 \\
\hline & 40 & 1.66 & 0.04 & 3.47 & 2.77 & 0.06 & 2.87 & 4.21 & 0.09 & 3.47 \\
\hline 120 & 18 & 0.00 & 0.00 & 0.00 & 0.00 & 0.00 & 0.00 & 0.00 & 0.00 & 0.00 \\
\hline & 21 & 0.00 & 0.00 & 0.00 & 0.00 & 0.00 & 0.00 & 1.05 & 0.02 & 0.39 \\
\hline & 24 & 0.58 & 0.01 & 0.68 & 1.32 & 0.03 & 0.56 & 2.30 & 0.05 & 0.55 \\
\hline & 27 & 1.07 & 0.02 & 1.08 & 1.99 & 0.04 & 1.12 & 3.36 & 0.07 & 1.05 \\
\hline & 30 & 1.21 & 0.03 & 1.42 & 2.30 & 0.05 & 1.39 & 3.54 & 0.07 & 1.30 \\
\hline & 33 & 1.40 & 0.03 & 2.21 & 2.40 & 0.05 & 1.77 & 3.73 & 0.08 & 2.18 \\
\hline & 36 & 1.46 & 0.03 & 2.85 & 2.48 & 0.05 & 2.30 & 3.79 & 0.08 & 2.81 \\
\hline & 40 & 1.51 & 0.03 & 3.66 & 2.58 & 0.06 & 3.83 & 3.84 & 0.08 & 3.61 \\
\hline 130 & 18 & 0.00 & 0.00 & 0.00 & 0.00 & 0.00 & 0.00 & 0.00 & 0.00 & 0.00 \\
\hline & 21 & 0.00 & 0.00 & 0.00 & 0.00 & 0.00 & 0.00 & 0.00 & 0.00 & 0.00 \\
\hline & 24 & 0.00 & 0.00 & 0.00 & 0.27 & 0.01 & 0.61 & 0.68 & 0.01 & 0.59 \\
\hline & 27 & 0.15 & 0.00 & 1.10 & 0.58 & 0.01 & 1.29 & 0.99 & 0.02 & 1.29 \\
\hline & 30 & 0.31 & 0.01 & 1.55 & 0.78 & 0.02 & 1.52 & 1.26 & 0.03 & 1.57 \\
\hline & 33 & 0.40 & 0.01 & 1.74 & 0.88 & 0.02 & 2.00 & 1.37 & 0.03 & 1.87 \\
\hline & 36 & 0.47 & 0.01 & 2.43 & 0.95 & 0.02 & 2.42 & 1.45 & 0.03 & 2.32 \\
\hline & 40 & 0.53 & 0.01 & 3.11 & 1.01 & 0.02 & 3.17 & 1.51 & 0.03 & 3.04 \\
\hline 210 & 18 & 0.00 & 0.00 & 0.00 & 0.00 & 0.00 & 0.00 & 0.00 & 0.00 & 0.00 \\
\hline & 21 & 0.00 & 0.00 & 0.00 & 0.00 & 0.00 & 0.00 & 0.00 & 0.00 & 0.00 \\
\hline & 24 & 0.00 & 0.00 & 0.00 & 0.00 & 0.00 & 0.00 & 0.00 & 0.00 & 0.00 \\
\hline & 27 & 0.00 & 0.00 & 0.00 & 0.00 & 0.00 & 0.00 & 0.13 & 0.00 & 1.33 \\
\hline & 30 & 0.00 & 0.00 & 0.00 & 0.00 & 0.00 & 0.00 & 0.24 & 0.01 & 1.54 \\
\hline & 33 & 0.00 & 0.00 & 0.00 & 0.19 & 0.00 & 2.24 & 0.41 & 0.01 & 1.81 \\
\hline & 36 & 0.00 & 0.00 & 0.00 & 0.28 & 0.01 & 2.53 & 0.50 & 0.01 & 2.14 \\
\hline & 40 & 0.07 & 0.00 & 2.70 & 0.34 & 0.01 & 3.37 & 0.56 & 0.01 & 2.93 \\
\hline 220 & 18 & 0.00 & 0.00 & 0.00 & 0.00 & 0.00 & 0.00 & 0.00 & 0.00 & 0.00 \\
\hline & 21 & 0.00 & 0.00 & 0.00 & 0.00 & 0.00 & 0.00 & 0.00 & 0.00 & 0.00 \\
\hline & 24 & 0.00 & 0.00 & 0.00 & 0.00 & 0.00 & 0.00 & 0.00 & 0.00 & 0.00 \\
\hline & 27 & 0.00 & 0.00 & 0.00 & 0.00 & 0.00 & 0.00 & 0.14 & 0.00 & 1.28 \\
\hline & 30 & 0.00 & 0.00 & 0.00 & 0.00 & 0.00 & 0.00 & 0.22 & 0.00 & 1.92 \\
\hline & 33 & 0.00 & 0.00 & 0.00 & 0.08 & 0.00 & 2.07 & 0.22 & 0.00 & 1.92 \\
\hline & 36 & 0.00 & 0.00 & 0.00 & 0.08 & 0.00 & 2.07 & 0.33 & 0.01 & 2.22 \\
\hline & 40 & 0.00 & 0.00 & 0.00 & 0.22 & 0.00 & 3.03 & 0.42 & 0.01 & 2.53 \\
\hline 230 & 18 & 0.00 & 0.00 & 0.00 & 0.00 & 0.00 & 0.00 & 0.00 & 0.00 & 0.00 \\
\hline & 21 & 0.00 & 0.00 & 0.00 & 0.00 & 0.00 & 0.00 & 0.00 & 0.00 & 0.00 \\
\hline & 24 & 0.00 & 0.00 & 0.00 & 0.00 & 0.00 & 0.00 & 0.00 & 0.00 & 0.00 \\
\hline & 27 & 0.00 & 0.00 & 0.00 & 0.00 & 0.00 & 0.00 & 0.00 & 0.00 & 0.00 \\
\hline & 30 & 0.00 & 0.00 & 0.00 & 0.00 & 0.00 & 0.00 & 0.00 & 0.00 & 0.00 \\
\hline & 33 & 0.00 & 0.00 & 0.00 & 0.00 & 0.00 & 0.00 & 0.00 & 0.00 & 0.00 \\
\hline & 36 & 0.00 & 0.00 & 0.00 & 0.00 & 0.00 & 0.00 & 0.00 & 0.00 & 0.00 \\
\hline & 40 & 0.00 & 0.00 & 0.00 & 0.00 & 0.00 & 0.00 & 0.06 & 0.00 & 2.95 \\
\hline TOTAL & 18 & 0.00 & 0.00 & 0.00 & 0.00 & 0.00 & 0.00 & 0.00 & 0.00 & 0.00 \\
\hline & 21 & 0.00 & 0.00 & 0.00 & 0.43 & 0.01 & 0.39 & 2.23 & 0.05 & 0.37 \\
\hline & 24 & 1.25 & 0.03 & 0.64 & 3.07 & 0.06 & 0.54 & 5.80 & 0.12 & 0.63 \\
\hline & 27 & 2.43 & 0.05 & 1.03 & 4.78 & 0.10 & 1.11 & 8.34 & 0.17 & 1.05 \\
\hline & 30 & 2.87 & 0.06 & 1.36 & 5.60 & 0.12 & 1.38 & 9.17 & 0.19 & 1.33 \\
\hline & 33 & 3.35 & 0.07 & 2.10 & 6.17 & 0.13 & 1.80 & 9.82 & 0.21 & 2.08 \\
\hline & 36 & 3.54 & 0.07 & 2.73 & 6.50 & 0.14 & 2.29 & 10.23 & 0.21 & 2.64 \\
\hline & 40 & 3.77 & 0.08 & 3.48 & 6.92 & 0.15 & 3.30 & 10.59 & 0.22 & 3.39 \\
\hline
\end{tabular}




\section{Appendix A: Documentation of costs:}

\section{Product Transportation System}

The National Petroleum Reserve Alaska (NPRA) was partitioned into eight economic sub-areas (Figure 4) in order to estimate oil transportation costs to the Trans-Alaska Pipeline System (TAPS). The assessment geologists allocated the resources assessed in each play to the economic sub-areas, and to Federal and non-Federal ownership within each sub-area.

About 80 percent of the total undiscovered oil resources are from the Beautfortian Upper Jurassic Play Northeast and Northwest (Table 1). Most of this oil was assigned to blocks 110, 120, and 130. Table 3 shows that sub-areas 110 and 120 were assigned about 70 percent of the total oil. With the oil assigned to sub-area 130 , the northern blocks $(110,120$, and 130) account for 85 percent of the mean estimate of undiscovered oil. Alternatively for gas, the sub-areas 130, 220, and 230 account for almost 70 percent of the mean estimate of gas in gas accumulations; with sub-areas 220 and 230 accounting for just over half of the total gas.

For this study, the pipeline transportation system was assumed built incrementally starting with the eastern most sub-areas $(110,210)$ and moving west. Consequently, it was assumed that sufficient capacity would be available for the development of discoveries from sub-areas 120 and 130. For example, the regional pipeline connection build-out for sub-area 120 will go from the middle of sub-area 120 (east-west) to the middle of 110 , where the pipeline build-out will connect with a pre-built part of the regional pipeline that transports oil from sub-area 110 to the Kuparuk field pipeline that transports the product to the Trans-Alaska Pipeline System (TAPS) Pump Station 1. A similar scheme was 
envisioned for the sub-areas to the south of 210 and 220, except the oil would be taken to TAPS Pump Station 2. Table A-1 shows the distances.

Within each sub-area, it is assumed that either a 12 -inch or 16 inch diameter lateral feeder line from the field to the regional pipeline would be constructed and operated as a separate common carrier. The size of the feeder line would depend on the accumulation size. New discoveries larger than 130 million barrels are assumed to use16 inch laterals and smaller discoveries are assumed to use 12-inch lateral feeder lines. The lateral distances assumed are also shown in Table A-1.

\section{Product Transportation Costs}

A regulated common carrier pipeline entity was assumed to build and operate the regional pipeline to Kuparuk and Pump Station 2. Pipeline tariff charges were set to assure investors a 12 percent after-tax return on investment. Cost functions presented in Broderick (1992, written communication) were updated to reflect reductions in costs since 1990. First, recent pipeline cost data gathered from the literature and from applications to the Alaska State Pipeline Office (T. Braden, Alaska Pipeline Office, written communication 1998). These data were analyzed and extrapolated to compute costs of pipelines of comparable sizes to those depicted by Broderick (written communication, 1992). These cost estimates were typical of the Prudhoe Bay-Kuparuk area and were increased by 30 percent to compensate for the absence of infrastructure and for the special costs of operating in the National Petroleum Reserve Alaska (NPRA). After review of the trend in 2001 materials cost indices, it was decided to use the investment cost function presented in Attanasi (1999) for computing pipeline investment costs (Figure A-1). The discrete shift in the cost function at distances of every 90 miles reflects the requirement 
of installation of facilities for an intermediate pump station (Young and Hauser, 1986; Broderick, written communication, 1992).

The estimated investment costs for the 24 inch regional pipeline segments servicing subareas 110, 120, and 130, respectively are 275, 294, and 294 million dollars. Similarly, investment costs for the 20 inch regional pipeline segments servicing sub-areas 210, 220, and 230 were 504, 278, and 484 million dollars, respectively.

The estimated tariff (trf) for the lateral feeder lines from the individual field to the regional pipeline was based on accumulation specific reserves. The following formula presented in Thomas and others (1993) and Broderick (written communication, 1992) was used to provide an approximation to the corresponding levelized charge:

$$
\operatorname{trf}=[(\text { investment cost }) /(\text { field recovery })] * 3.35
$$

where the investment cost was calculated for an 12 inch or 16 inch diameter line with the required distances based on those distances shown in Table A-1. Required investment for the short 12-inch and 16-inch lateral feeder lines were estimated at 1.2 million and 1.6 million dollars per mile for the Prudhoe Bay area and inflated by 30 percent for the NPRA. Table A-2 shows the distances and example calculations of pipeline tariffs used in the economic analysis for accumulations with 300 and 600 million barrels of recoverable oil.

\section{Field Development Costs}

It was generally assumed that accumulations were developed as stand-alone fields. Field development costs include well costs (drilling and completion) and the facilities costs. Actual development costs will depend on site-specific characteristics of prospects. Play analysis, however, is not location specific. In the process of developing generic cost 
functions, a number of simplifying assumptions were made to keep the economic analysis tractable. Undiscovered accumulations were grouped into field size categories starting with 16 to 32 million barrels of oil in oil accumulations, 32 to 64 million barrels, 64 to 128 million barrels, and so forth. Undiscovered accumulations were also grouped by 5,000-foot depth intervals. Development cost estimates for a representative accumulation for each size and depth class were estimated and tested against an economic screen to determine whether all the accumulations in the size and depth category were commercially developable.

\section{Field design}

A conventional well spacing of 160 acres was assumed. With this assumption, average well productivity (recoverable reserves per well) for an accumulation was computed by using the simulated reservoir attribute values (Scheunemeyer, 2002, unpublished data). For a single accumulation, the number of production wells required for development was computed as the ratio of the technically recoverable oil divided by the average well productivity.

For each accumulation size and depth category, average well productivity (based on an assumed production well spacing) was calculated as the weighted average (based on assessed technically recoverable oil volume) of the well productivity of the predicted accumulations occurring in that size and depth category. Well productivity estimates varied across different depth intervals and within the same field-size category, reflecting the broad variations in reservoir quality of the plays occurring in the depth interval.

As noted in the text nearly seven-eighths of the oil assessed was assigned to depths between 5,000 and 10,000 feet. Conventional well productivity values for this depth are shown in Table A-3. They are representative of the productivity computed from the 
simulations of the reservoir model. Beaufortian Upper Jurassic plays. These productivity values do not reflect the application of horizontal drilling technologies that might be applied if site-specific conditions are favorable. In order to include the effect of horizontal production wells in the analysis, it was assumed that the conventional well productivity's shown in Table A-3 could be doubled by drilling horizontal wells with a lateral (horizontal) section of sufficient length. Calculations comparing optimal well locations and drainage patterns indicated that the resources accessed by four conventional wells at 160 acre spacing could be drained by two strategically placed horizontal wells with horizontal laterals of about 3000 feet (Jim Craig, MMS, verbal communication, 2002).

Development drilling and completion costs

Estimated total drilling costs for conventional wells are based on the number of wells and well drilling and completion costs. The costs of drilling and completing for production wells were estimated from the historical costs reported in the Joint Association Survey (JAS) on 1996-2000 drilling costs (American Petroleum Institute, 1997, 1999, 2000, 2001) for Alaska oil wells. Data from the cost survey were examined, and costs were estimated for three 5,000-foot vertical depth intervals (Note; The assessment geologists did not assign any oil to depths greater than 15,000 feet). The JAS data showed that the 1999 and 2000 per foot costs had increased relative to previous years. The empirical data as well as the initial estimates for 2001 were based on the level of infrastructure in the vicinity of Prudhoe Bay. Cost estimates for NPRA were increased by 30 percent over the costs typical of the Prudhoe Bay area to offset expected extra costs due to the absence of infrastructure or special environmental precautions in the NPRA. The estimated costs of drilling and completing conventional oil production wells in the NPRA are $\$ 2.5$ million at depths to 
5,000 feet, $\$ 3.2$ million at depths of 5,000 to 10,000 feet, and $\$ 5.16$ million at depths greater than 10,000 feet.

The following example illustrates the cost estimation procedure for horizontal wells. Suppose the target vertical depth is at 8,000 feet. The vertical portion of the well is deviated until it reaches the target depth, adding as much as 20 percent to drilling length. At the target depth, a lateral portion of 3,000 feet is drilled. The average per foot drilling and completion cost of $\$ 270$ per foot was assumed to be characteristic for the Prudhoe Bay area. This rate was increased by 30 percent for drilling in the NPRA, so the following relation was used to estimate horizontal development well drilling and completion costs for targets at a vertical depth of 8,000 feet:

$[8000 \mathrm{ft}(1.2)(\$ 270 / \mathrm{ft})+3000 \mathrm{ft} * \$ 270 / \mathrm{ft})] * 1.3=\$ 4.4$ million per well

In this example, the horizontal well adds about 30 percent to the costs of drilling and completing a conventional development well but the horizontal wells reduce the required number of development-wells by half. In addition, it was assumed that 0.4 injection wells will be drilled for each conventional production well (National Petroleum Council, 1981b; Young and Hauser, 1986; Broderick, written communication, 1992). For accumulations developed by horizontal wells, one injection well was assumed to be required for each production well. This assumption insures that there are a sufficient number of injection wells for pressure maintenance via gas and water injection.

\section{Facilities Costs}

Production facilities include drill pads, flow lines from drilling sites, a central processing unit, and infrastructure (and amenities) required for housing workers. Facilities design and costs depend on peak production rates and field size. As of the 
beginning of 1998, there are seven stand-alone fields operating in Northern Alaska.

These fields include Prudhoe Bay, Kaparuk, Lisburne, Milne Point, Endicott, Badami, Alpine, and Northstar. British Petroleum is in the process of shutting down Badami. Endicott, which started producing in 1987, was the last stand-alone field developed until Badami, Alpine, and Northstar came on-line in the early 2001 and 2002.

Little information about the costs of facilities in oil development in Northern Alaska from private operators is in the public domain. A version of the Northstar field development plan, along with generic drilling, pipeline, and facilities costs, was made public by British Petroleum when it requested relief of profit sharing provisions of the State lease. With this information and with inferred facilities cost estimates from published reports for other fields under development, a cost relationship that specified investment cost per barrel as a function of peak fluid flow rates for facilities for fields in the Prudhoe Bay area was calibrated ${ }^{1}$. These estimates, when applied to new discoveries in the NPRA, were increased 30 percent to compensate for the absence of infrastructure and special rules associated with field development in the NPRA.

A previous study (Attanasi, 1999) provided the basis for the facilities investment cost estimates by accumulation size class (Table A-4). The flurry of activity in the oil industry during 2000 resulted in some inflation in oil field equipment costs but there appears some return to earlier levels. Moreover, implementation of new technology continues to reduce costs in Northern Alaska (Williams, 2002a; Advance Resources International, 2001). The costs shown in Table A-4 were increased by 5 percent to account for general

\footnotetext{
${ }^{1}$ The costs relation was similar in form to those presented by the National Petroleum Council (1981b) and Young and Hauser (1986).
} 
cost increases in oil field equipment that occurred from 1996 to 2000 (American Petroleum Institute, 2001).

The Point McIntyre, Niakuk, North Prudhoe Bay, and West Beach fields share the central processing facilities at the Lisburne field. Use of the central processing unit at the Lisburne field saved the Point McIntyre operators 35 percent in overall facilities investment costs (Thomas and others, 1993). Such savings, however, are highly sitespecific. Distances between production wells and central processing units may limit sharing opportunities. In this economic study, facilities-sharing was limited to sub-areas 110 and 120 and to fields having less than 130 million barrels of technically recoverable oil. It was assumed that facilities sharing would, on average, result in a 30 percent reduction in facilities investment costs.

Field production profile

Future discoveries are assumed to attain peak annual rates of production equal to the percentage of the accumulation's ultimate oil recovery. Table A-5 shows the assumptions relating to the accumulation production profile. Those accumulations having less than 130 million barrels of recoverable oil are assumed to reach peak production in the second production year and to maintain the peak production level for 2 years, after which annual production will decline 12 percent per year. Accumulations larger than 130 million barrels are assumed to reach peak production in the third year, maintain the peak production level for 2 years (through year 5), after which annual production will decline at 12 percent per year. Accumulations larger than 1 billion barrels of oil are assumed to reach peak production in year 3, maintain the peak 
production level for 3 years (through year 6), after which annual production will decline at a rate of 12 percent per year.

At first glance, the 12 percent field production decline rate appears to be very rapid. Observed field decline rates are typically less rapid because of the application of well enhanced recovery techniques to prolong field life. However, the success of appropriate enhanced recovery techniques will depend on site-specific conditions. Recovery factors of oil-in-place that were posited by the assessors were assumed to include primary production and water-flood/pressure maintenance production, but not the maximum production that might be recoverable by enhanced recovery.

The volume of produced water was projected with the production profile for oil, the degree of accumulation depletion, and functions that relate water cut percentages to the percentage of reservoir depletion. For undiscovered accumulations in sub-area 110, 120 and 130 the function presented in Arco and others (1998) was used (Figure A-2). Else where the water cut function for the Kuparuk reservoir (see figure 3, from Thomas and others, 1991) was applied. The figures show the percentage water (water cut) expected in production with depletion of the accumulation. Volumes of natural gas and natural gas liquids production were projected using annual oil production, the expected values of the gas to oil ratio, and NGL to gas ratios associated with the representative accumulation's size and depth classification.

Operating costs

Field operating costs include labor, supervision, overhead and administration, communications, catering, supplies, consumables, well service and workovers, facilities maintenance and insurance, and transportation. Some of these costs, such as well work- 
over and labor costs, have declined dramatically during the last decade due to the introduction of coiled tubing technology and to the institution of automation in field operations. Annual operating costs are characterized as a function of daily fluid volumes (National Petroleum Council, 1981a, Young and Hauser, 1986). The annual operating cost function presented by Young and Hauser (1986) was adjusted using the Energy Information Administration's index of oil field operating costs for 1996 and then for 2000 (Energy Information Administration, 1997, 2002). Figure A-4 shows annual operating costs as a function of the daily fluid production. These fluid (hydrocarbon and water) volumes from production were projected in annual increments using field production forecasts and water cut functions (Figures A-2 and A-3), so that per barrel costs of oil reflect the increases in costs that result from a higher water cut as the accumulation is depleted. 
Appendix B-1 Assumptions relating to taxes and royalties
Alaska Taxes
Severance Tax for oil:
$12.25 \%$ for years 1 through 5 adjusted for economic limit factor (elr)
$15.00 \%$ after year 5 adjusted for the economic limit factor
floor of $\$ 0.80$ per barrel adjusted for the economic limit factor
elr $=(1-(300 / A D W R))^{a}$
where $\mathrm{a}=(150000 / \mathrm{ADFR})^{1.5333}$
ADWR $=$ average daily production per producing well in barrels per day $(\mathrm{bb} / \mathrm{d})$
$\mathrm{ADFR}=$ average daily field production (bbo/d)
Severance Tax for gas:
$10.00 \%$ adjusted for the economic limit for
floor $\$ 0.064$ per thousand cubic feet adjusted for the economic limit factor elr $=(1-(3000 /$ ADWR $))$
ADWR $=$ average daily production per producing well $(\mathrm{mcf} / \mathrm{d})$
For both cases, if elr is less than or equal to zero, then the severance tax is zero
Ad valorem tax
Tax equal to 2 percent of the economic value of pipelines, facilities, and
equipment. For pipelines, a 25-year life was assumed. For tangible well costs, oil
field equipment costs, and facilities costs, depreciation of the asset was based on the unit of production method.

\section{State Income tax}

For planning purposes, Alaska state agencies use 1.4 to 3.0 percent of net income. The rate used here was 2.4 of net income. Depreciation of capital assets associated with oil field development is permitted on a unit of production basis.

For other capital, depreciation depends on the economic life of the equipment.

State conservation tax

Tax is $\$ 0.004$ per barrel, and the conservation surcharge tax is $\$ 0.03$ per barrel.

Federal Taxes

Federal royalty rate

Royalty rate is considered to be a payment to the landowner and the rate was assumed to be 16.7 percent of gross revenue for the high potential sub-area 110 . For other sub-areas, a rate of 12.5 percent of gross revenue was assumed.

Federal income taxes

A Federal income tax rate of 35 percent of taxable income was assumed. Based on the 1986 Tax Reform Act, 30 percent of development well drilling costs is classified as tangible cost and is therefore capitalized over 7 years. Of the remaining 70 percent of drilling cost (that is, the intangible drilling costs), 30 percent is depreciated over 5 years and the remaining 70 percent is expensed immediately. 
Table A-1. Distances assumed for transport of crude oil to the Trans-Alaska Pipeline System (TAPS).

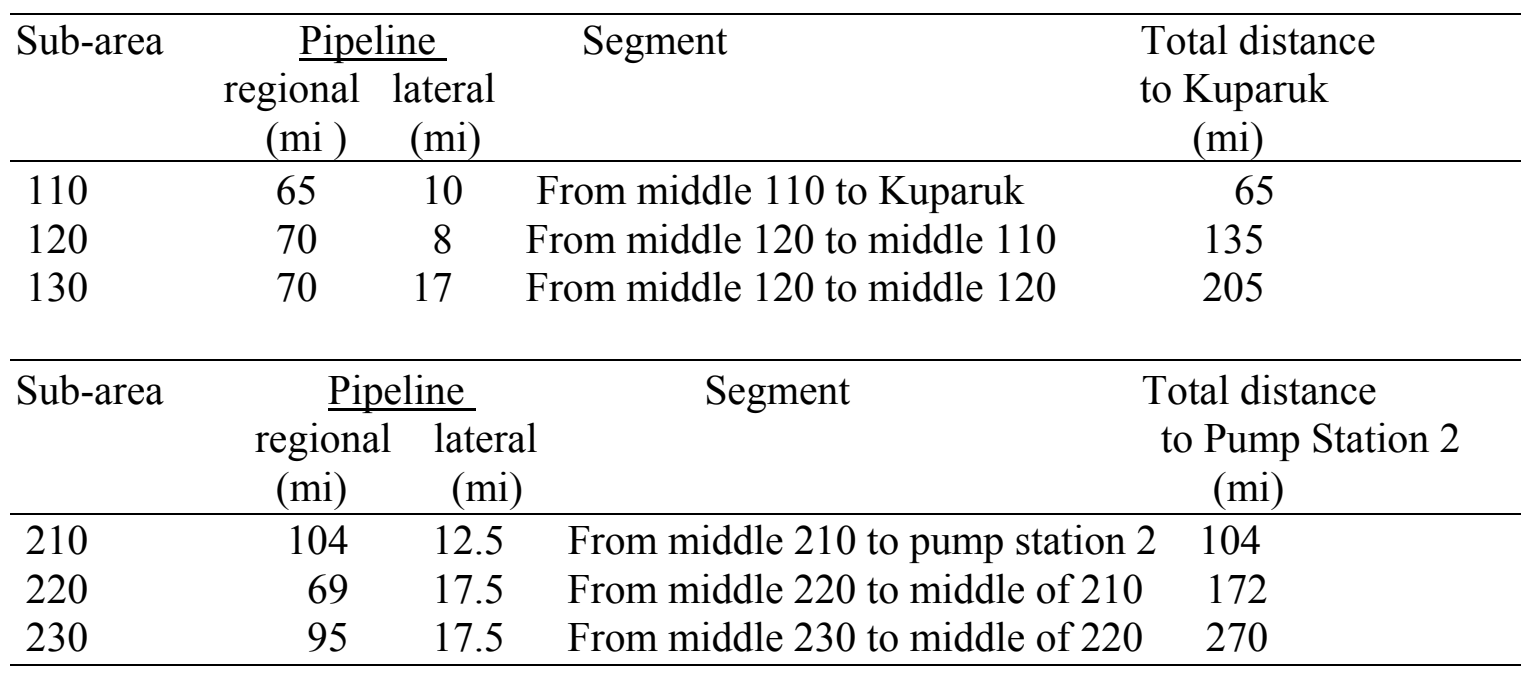


Table A-2. Estimated costs (in dollars per barrel) for transport used from the accumulation to the Trans-Alaska Pipeline System (TAPS).

\begin{tabular}{|c|c|c|c|c|c|c|c|}
\hline & $\begin{array}{l}\text { Segment } \\
\text { distance }\end{array}$ & & & Lateral size & & $\begin{array}{l}\text { Estimate ta } \\
\text { Lateral size }\end{array}$ & ariff to TAPS \\
\hline North & miles & $500 \mathrm{~kb} / \mathrm{d}$ & +21 cents $^{*}$ & ${ }^{*} 12$ inch $^{* *}$ & 16 inch $^{* * *}$ & 12 inch $^{* *}$ & 16 inch $^{* * *}$ \\
\hline 110 & 65 & \begin{tabular}{|r|}
0.42 \\
\end{tabular} & \begin{tabular}{|r|}
0.63 \\
\end{tabular} & 0.17 & \begin{tabular}{|r|}
0.12 \\
\end{tabular} & 0.80 & 0.75 \\
\hline 120 & $70+65$ & 0.87 & 1.08 & 0.31 & 0.21 & 1.39 & 1.29 \\
\hline 130 & $70+70+65$ & 1.32 & 1.53 & 0.30 & 0.20 & 1.83 & \begin{tabular}{|l|}
1.73 \\
\end{tabular} \\
\hline South & & $300 \mathrm{~kb} / \mathrm{d}$ & not needed & & & & \\
\hline 210 & 104 & \begin{tabular}{|r|}
1.29 \\
\end{tabular} & \begin{tabular}{|r|}
1.29 \\
\end{tabular} & 0.22 & 0.15 & 1.51 & 1.44 \\
\hline 220 & $69+104$ & 2.00 & 2.00 & 0.30 & 0.20 & 2.30 & 2.20 \\
\hline 230 & $97+69+104$ & 3.24 & 3.24 & 0.30 & 0.20 & 3.54 & 3.44 \\
\hline
\end{tabular}

$\mathrm{kb} / \mathrm{d}=$ thousand barrels per day.

* Based on charge of 21 cents from Kuparuk field to TAPS Pump Station 1.

**Based on an accumulation with 300 million barrels of recoverable oil.

*** Based on an accumulation with 600 million barrels of recoverable oil. 
Table A-3. Conventional well productivity, by oil accumulation size class, for accumulations in the Beaufortian Upper Jurassic oil plays of the National Petroleum Reserve Alaska (based on data from the mean volume estimate).

$\begin{array}{cc}\begin{array}{cc}\text { Accumulation } \\ \text { Size }\end{array} & \begin{array}{c}\text { Well } \\ \text { Productivity }\end{array} \\ \text { Class } & \text { MMBO/Well } \\ 16-32 & 1.03 \\ 32-64 & 1.82 \\ 64-128 & 2.21 \\ 128-256 & 2.45 \\ 256-512 & 2.87 \\ 512-1024 & 3.67 \\ 1024-2048 & 5.28\end{array}$


Table A-4. Estimates of facilities investment cost in 1996 dollars, from Attanasi (1999).

\begin{tabular}{|c|c|}
\hline Field size & $\begin{array}{c}\text { Investment } \\
\text { Cost }\end{array}$ \\
\hline (MMBO) & $\$ / \mathrm{bbl}$ \\
\hline 32 & 7.75 \\
\hline 48 & 5.83 \\
\hline 64 & 4.77 \\
\hline 96 & 3.59 \\
\hline 128 & 2.97 \\
\hline 192 & 2.43 \\
\hline 256 & 2.10 \\
\hline 384 & 1.72 \\
\hline 512 & 1.49 \\
\hline 768 & 1.22 \\
\hline 1024 & 1.05 \\
\hline 1536 & 0.86 \\
\hline
\end{tabular}


Table A-5. Accumulation production profiles assumed for new discoveries in the National Petroleum Reserve Alaska.

\begin{tabular}{llll}
$\begin{array}{c}\text { Accumulation } \\
\text { sizes }\end{array}$ & $\begin{array}{l}\text { Peak rate as } \\
\text { Years percent of } \\
\text { buildup ultimate }\end{array}$ & $\begin{array}{l}\text { Years of peak } \\
\text { production }\end{array}$ \\
\hline $\begin{array}{lll}\text { MMBO } \\
8-16\end{array}$ & 2 & 11 & 3 \\
$16-32$ & 2 & 11 & 3 \\
$32-64$ & 2 & 11 & 3 \\
$64-128$ & 2 & 11 & 3 \\
$128-256$ & 2 & 11 & 3 \\
$256-512$ & 2 & 11 & 3 \\
$512-1024$ & 3 & 10 & 4 \\
$1024-2048$ & 3 & 9 & 4
\end{tabular}


Figure captions

Figure 1. Map of Northern Alaska showing the locations of the National Petroleum Reserve Alaska (NPRA), the Arctic National Wildlife Refuge (ANWR), and the 1002 Area of the Arctic National Wildlife Refuge. The Trans-Alaska Pipeline System (TAPS) is also designated as well as part of the feeder pipeline network to the east and west of TAPS.

Figure 2. Size distribution of undiscovered conventional oil accumulations associated with $95^{\text {th }}$ fractile estimate, mean estimate, and the $5^{\text {th }}$ fractile estimate of the assessed distribution of oil in oil accumulations for the Federal part of the National Petroleum Reserve Alaska study area.

Figure 3. Size distribution of undiscovered conventional gas accumulation associated with the $95^{\text {th }}$ fractile estimate, mean estimate, and the $5^{\text {th }}$ fractile estimate of the assessed distribution of gas in gas accumulations for the Federal part of the National Petroleum Reserve Alaska study area.

Figure 4. Map showing the partitioning of the Federal part of the National Petroleum Reserve Alaska study area into economic sub-areas. The numbers in parenthesis represent the area in millions of acres.

Figure 5. Incremental costs, in 2001 dollars per barrel, of finding, developing, producing, and transporting crude oil from undiscovered accumulations in the Federal part of the National Petroleum Reserve Alaska study area. (Under assumptions of this analysis incremental costs are set equal to market prices).

Figure A-1. Pipeline investment cost estimates for the regional pipe as a function of distance (from Attanasi, 1999). The discontinuity in the function at 80 miles indicates the requirement for an intermediate pump station.

Figure A-2. Percentage of water in oil production stream as a function of reservoir depletion for Alpine-type reservoirs (data are from Arco Alaska, Inc., and others, 1998).

Figure A-3. Percentage of water in oil production stream as a function of reservoir depletion for Kuparuk-type reservoirs (data are from Thomas, and others, 1991).

Figure A-4. Design operating costs as a function of average daily fluid production rates in thousands of barrels per day (data are from Attanasi,1999). 


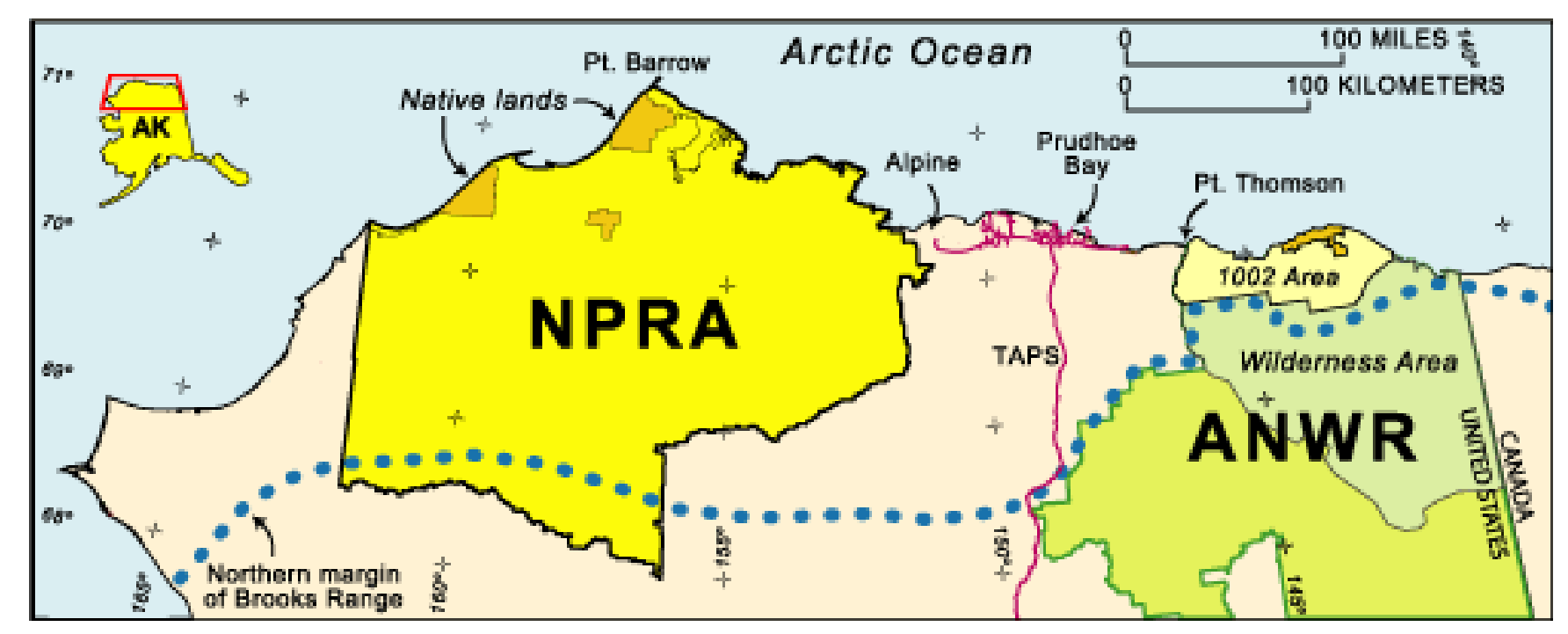

Figure 1. 


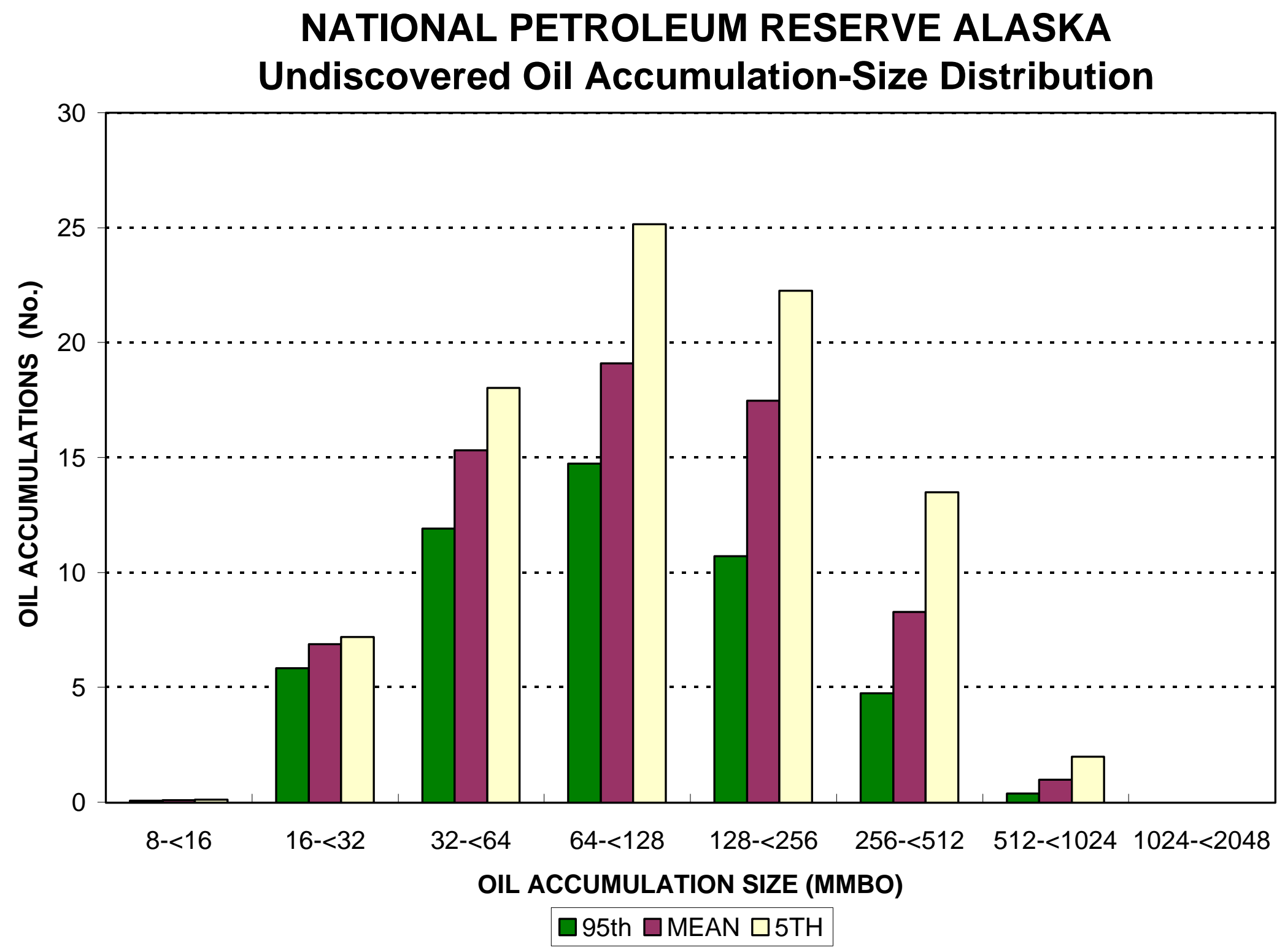

Figure 2. 


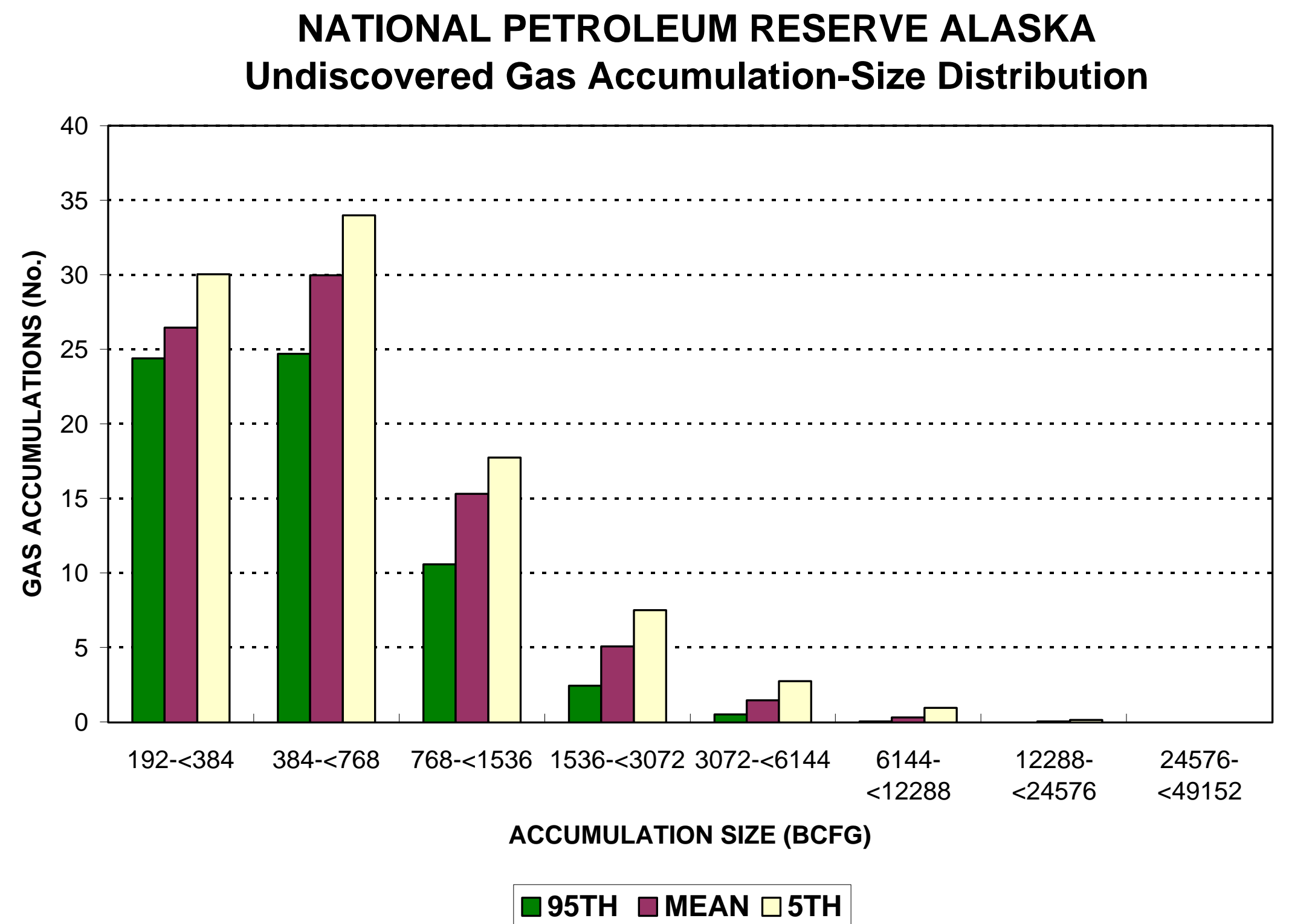

Figure 3. 


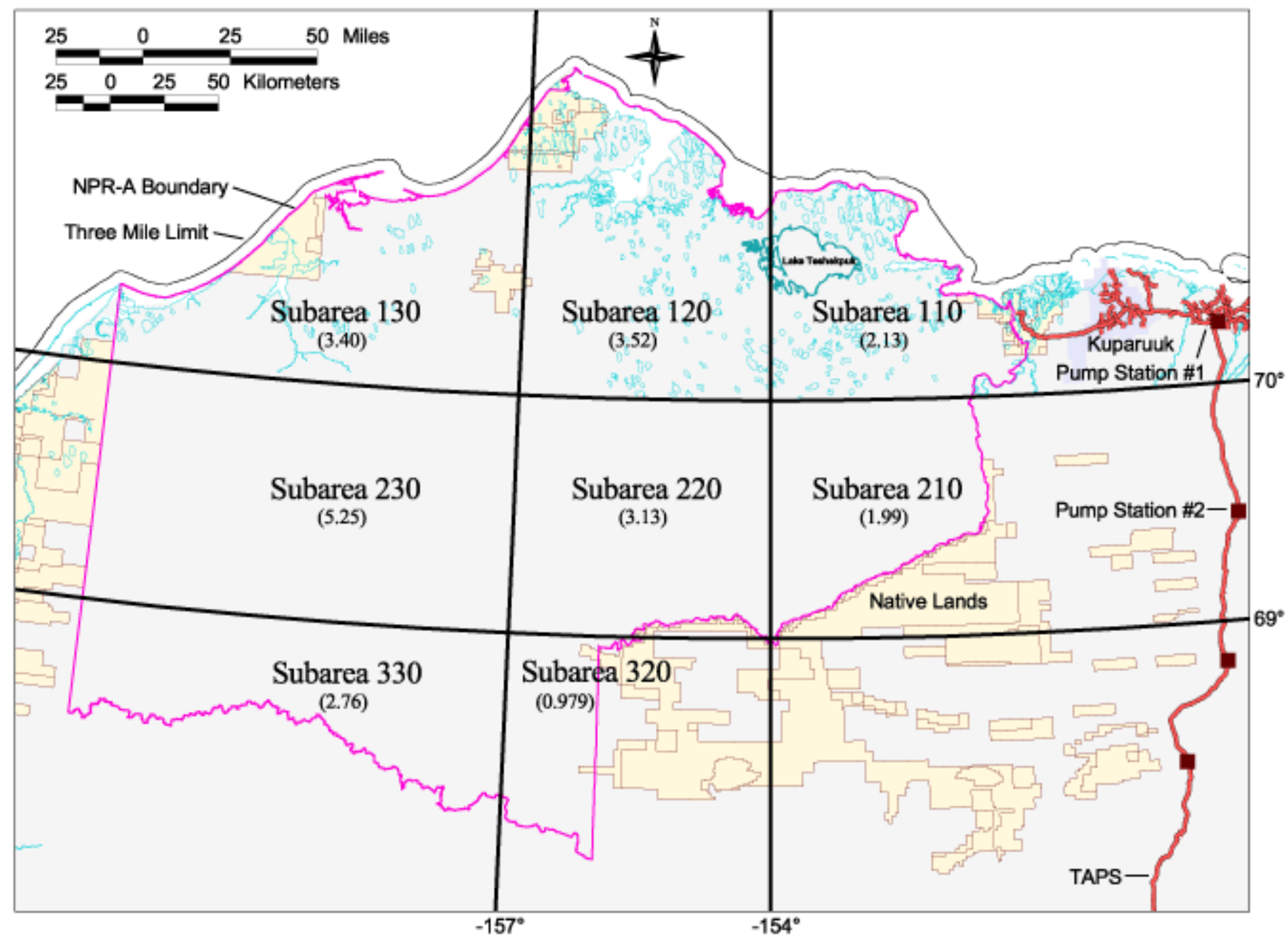

Figure 4. 


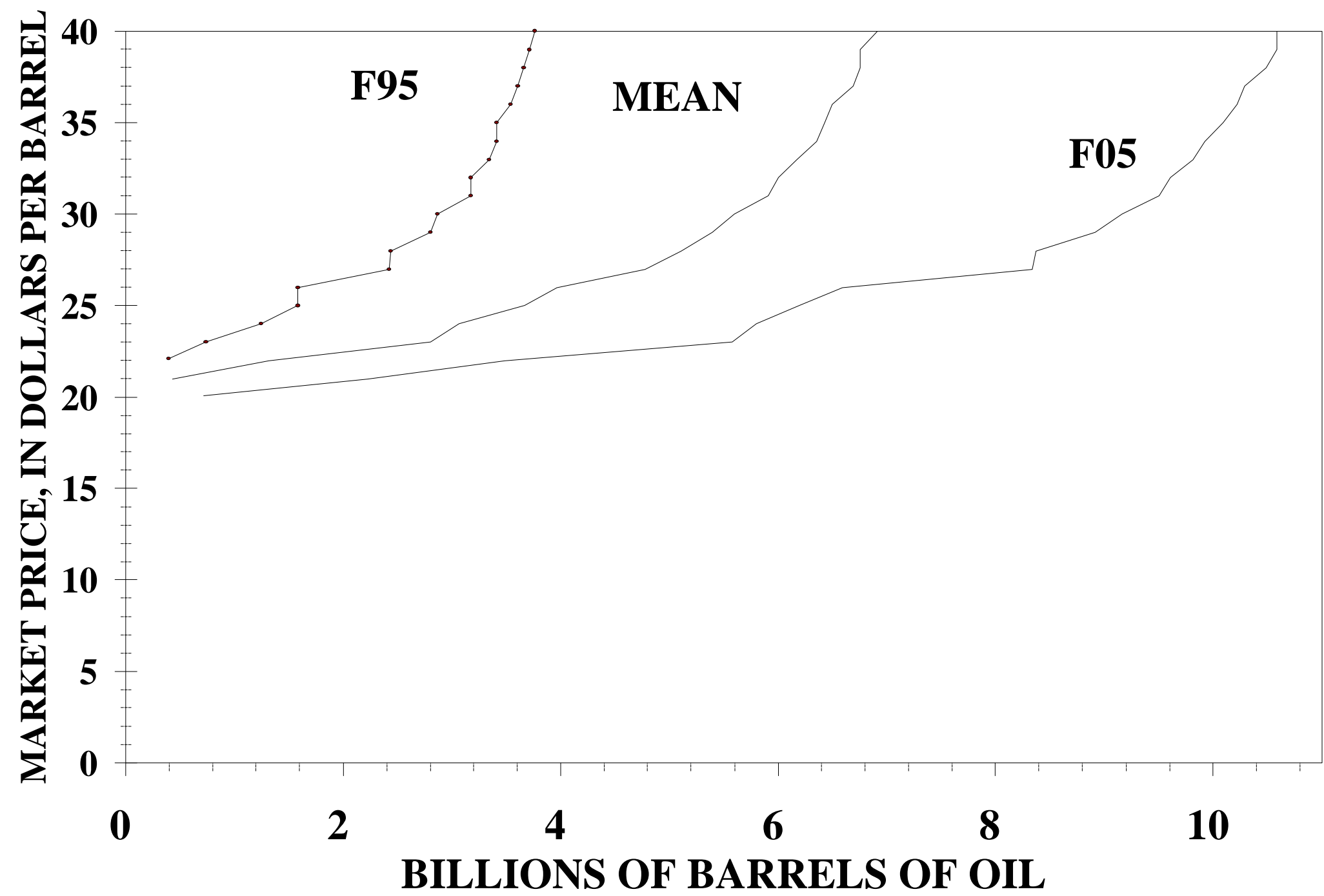

Figure 5. 


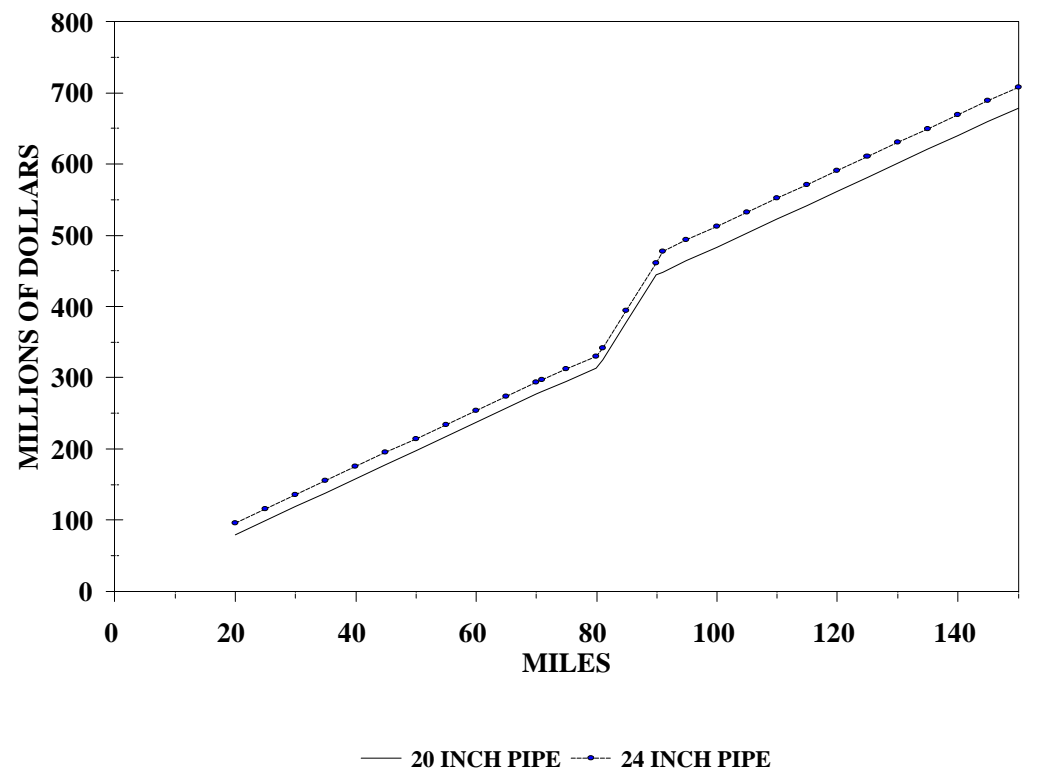

Figure A-1. 


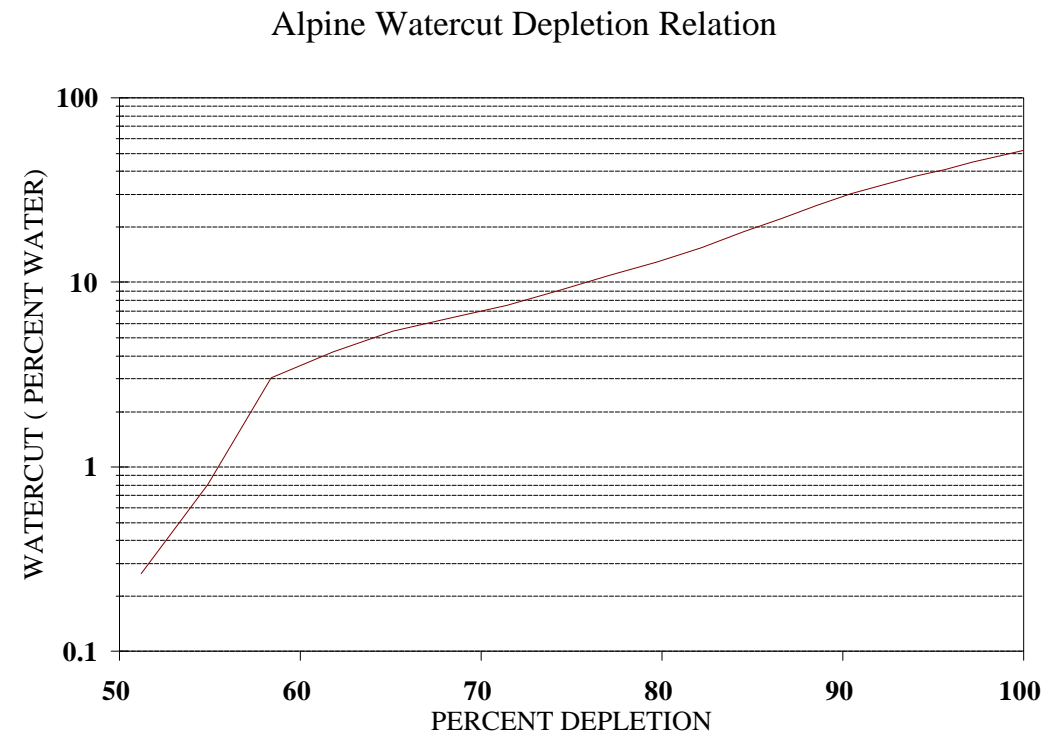

Figure A-2. 
Kuparuk Depletion Relation

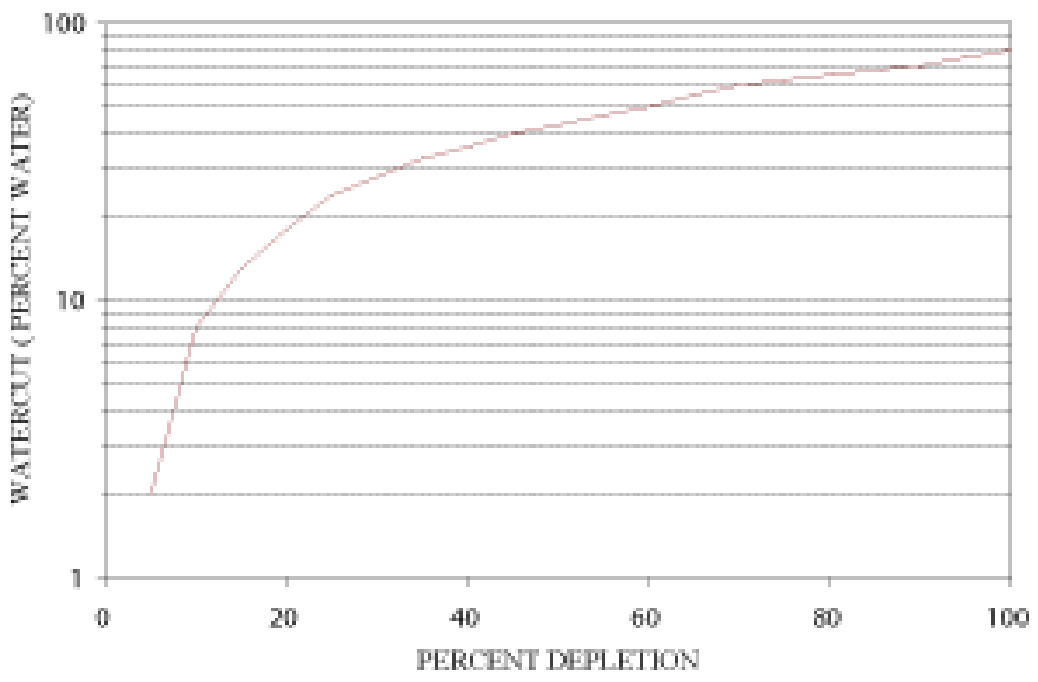

Figure A-3. 


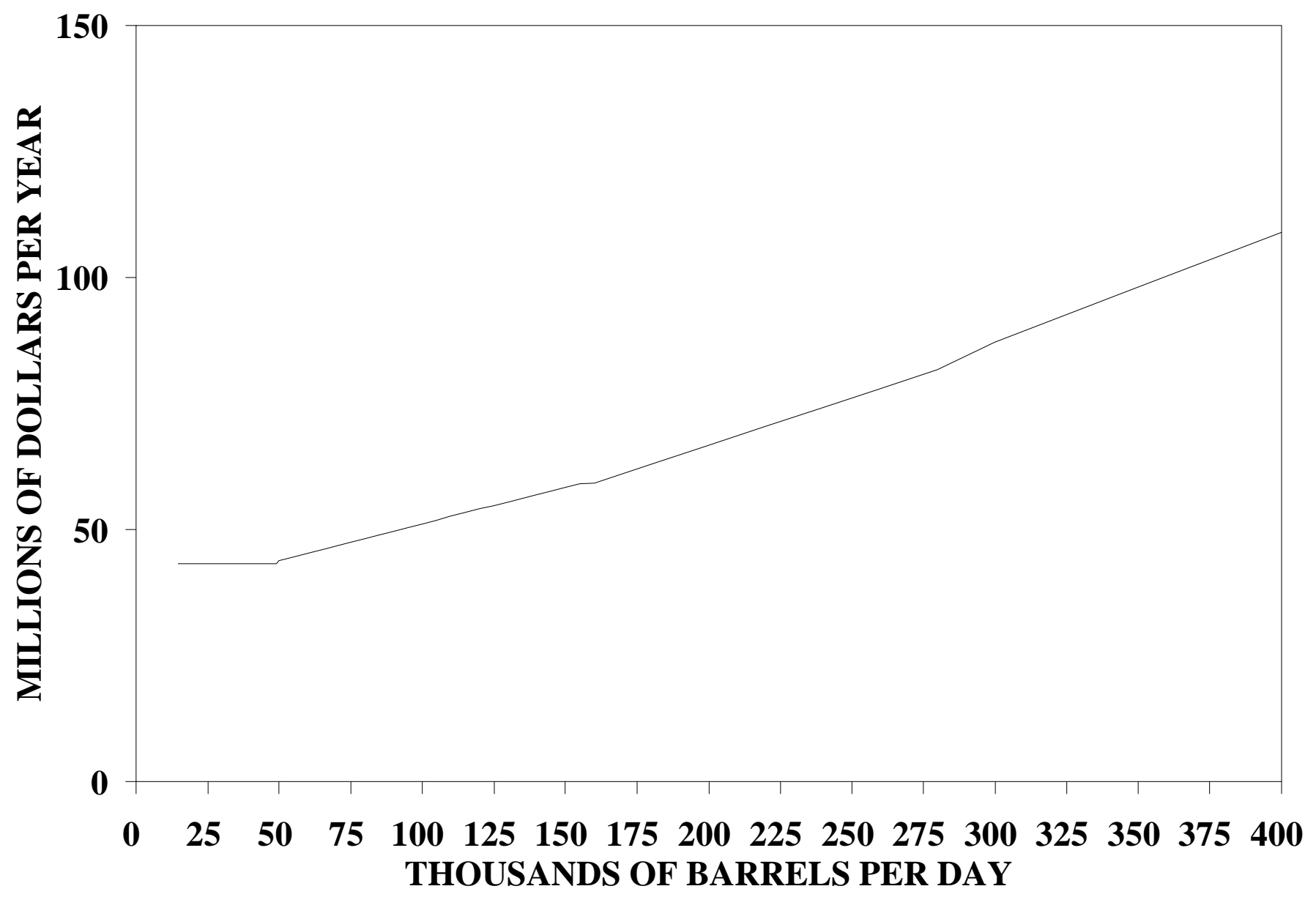

Figure A-4. 